\title{
Regulated expression of three C/EBP isoforms during adipose conversion of 3T3-L1 cells
}

\author{
Zhaodan Cao, Robert M. Umek, and Steven L. McKnight ${ }^{1}$ \\ Department of Embryology, Howard Hughes Research Laboratories, Carnegie Institution of Washington, Baltimore, \\ Maryland 21210 USA
}

\begin{abstract}
In an effort to identify protein factors that play a regulatory role in the differentiation of adipocytes, we have isolated two genes that encode polypeptides related to CCAAT/enhancer-binding protein (C/EBP; hereafter termed C/EBP $\alpha$ ). The proteins encoded by these C/EBP-related genes, termed C/EBP $\beta$ and C/EBP $\delta$, exhibit

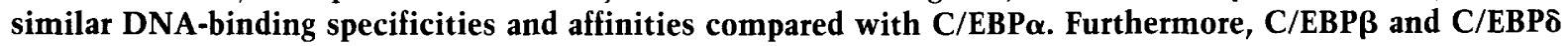
readily form heterodimers with one another as well as with C/EBP $\alpha$. The transcriptional activating capacity of these two newly identified C/EBP isoforms was demonstrated by transient transfection experiments in which expression vectors encoding C/EBP $\beta$ and C/EBPS were observed to induce transcription from the promoter of the serum albumin gene in cultured hepatoma cells. The mRNAs encoding C/EBP $\beta$ and C/EBPS were detected in a number of tissues, most of which corresponded to sites of expression of $C / E B P \alpha$. The expression pattern of $\mathrm{C} / \mathrm{EBP} \beta$ and C/EBPS during adipose conversion of 3T3-L1 cells was examined by Western and Northern blotting assays. In contrast to the expression profile of the gene encoding $\mathrm{C} / \mathrm{EBP} \alpha$, whose product is not detectable until the late phase of adipocyte differentiation, the $c / e b p \beta$ and $c / e b p \delta$ genes were actively expressed very early during adipocyte differentiation. Moreover, transcription of the $c / e b p \beta$ and $c / e b p \delta$ genes

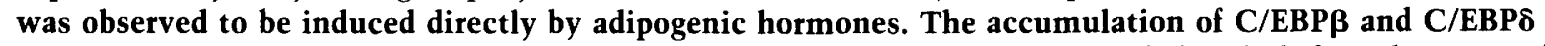
reached a maximal level during the first 2 days of differentiation and declined sharply before the onset of $\mathrm{C} / \mathrm{EBP} \alpha$ accumulation. The temporal pattern of expression of these three C/EBP isoforms during adipocyte differentiation may reflect the underpinnings of a regulatory cascade that controls the process of terminal cell differentiation.
\end{abstract}

[Key Words: Transcription factors; cell differentiation; bZIP proteins]

Received May 6, 1991; revised version accepted June 14, 1991.

CCAAT/enhancer-binding protein $(\mathrm{C} / \mathrm{EBP})$ is a transcription factor expressed primarily in liver, fat, and intestinal tissues (Birkenmeier et al. 1989). C /EBP expression is restricted to terminally differentiated cells, and evidence has been presented indicating that it can stimulate the transcription of several genes that mark the differentiated state (Christy et al. 1989; Friedman et al. 1989; Kaestner et al. 1990; Park et al. 1990). These observations led to the speculation that C/EBP may play an important role in establishing and/or maintaining the state of terminal cell differentiation.

The in vitro conversion of 3T3-L1 adipoblasts to adipocytes has provided a useful system to study the putative role of $\mathrm{C} / \mathrm{EBP}$ in cell differentiation. The 3T3-L1 cell line was originally isolated from mouse fibroblasts (Green and Kehinde 1974). These cells exhibit a fibroblast-like morphology and proliferate continuously when maintained in growth medium. Upon appropriate hormonal stimulation, 3T3-L1 cells terminate mitotic

${ }^{1}$ Corresponding author. growth and acquire morphological and enzymatic properties characteristic of adipocytes (Green and Kehinde 1975; Russell and Ho 1976; Rubin et al. 1977; Student et al. 1980|. Several lines of evidence have indicated that C/EBP may participate in the terminal differentiation of 3T3-L1 cells. First, the temporal profile of C/EBP expression correlates with the progress of adipocyte differentiation. The protein is undetectable in proliferating adipoblasts but accumulates to a substantial level in differentiated adipocytes (Birkenmeier et al. 1989). Furthermore, premature expression of C/EBP impedes cell proliferation and accentuates differentiation in the presence of adipogenic hormones (Umek et al. 1991). Second, C/EBP is capable of trans-activating genes encoding several adipose-specific proteins, including a fatty acid-binding protein variously termed 422 or aP2, stearoyl coenzyme $\mathrm{A}(\mathrm{CoA})$ desaturase, and the insulin-responsive glucose transporter (Christy et al. 1989; Kaestner et al. 1990). Despite these observations, premature expression of C/EBPo is not sufficient to convert adipoblasts to adipocytes (Umek et al. 1991). This later observation indicates 
that adipogenesis probably requires the function of uncharacterized regulatory proteins in addition to C/EBP.

C/EBP belongs to a class of DNA-binding proteins termed bZIP proteins (Vinson et al. 1989). The bZIP domain contains a region rich in basic amino acids linked to a dimer-forming region called the leucine zipper (Landschulz et al. 1988b, 1989; Vinson et al. 1989). bZIP proteins are capable of forming homotypic and heterotypic dimers by their leucine zippers (reviewed by $\mathrm{P}$. Lamb and S.L. McKnight, in prep.). A different class of DNA-binding proteins, termed helix-loop-helix (HLH) proteins, also mix as homotypic and heterotypic dimers (Murre et al. 1989a,b). Certain members of the HLH family of transcription factors have been shown to play important roles in cell determination and differentiation (for reviews, see Olson 1990; Barinaga 1991). In light of these relationships, we reasoned that the uncharacterized regulatory proteins required for adipogenesis might be C/EBP related. Guided by this notion, we searched for C/EBP-related genes expressed in differentiating adipocytes.

Here we report the isolation and characterization of two genes, termed $c / e b p \beta$ and $c / e b p \delta$, whose expression is regulated in a temporal manner during adipogenesis. $c / e b p \beta$ has been described previously and variously termed NF-Il6, LAP, Il6-DBP, and AGP/EBP (Akira et al. 1990; Chang et al. 1990; Descombes et al. 1990; Poli et al. 1990). To our knowledge, c/ebp $\delta$ has not been described previously. Both genes encode bZIP proteins that bind to DNA in a manner highly similar to C/EBP. Moreover, C/EBP $\beta$ and C/EBP $\delta$ can cross-dimerize with one another as well as with C/EBP, hereafter termed C/EBP $\alpha$. Surprisingly, transcription of the genes encoding C/EBP $\beta$ and C/EBP $\delta$ is directly responsive to adipogenic hormones, which is reflected in the accumulation of these proteins during the early stage of adipocyte differentiation. The expression profiles of C/EBP $\beta$ and C/EBP $\delta$ during adipogenesis raise the possibility that these transcription factors perform important regulatory functions early during the process of terminal differentiation.

\section{Results}

\section{Isolation of $\mathrm{c} / \mathrm{ebp} \beta$ and $\mathrm{c} / \mathrm{ebp} \delta$ genes}

To search for genes related to that which encodes $\mathrm{C} / \mathrm{EBP} \alpha$, we constructed a cDNA library using mRNA isolated from 3T3-L1 cells midway through the differentiation program. The library was screened with 150 -bp DNA probe encoding the bZIP domain of C/EBP $\alpha$. The screen was conducted at moderate hybridization stringency so as to allow cDNA clones bearing similar sequences to hybridize to the probe. Thirty hybridizationpositive bacteriophage were isolated after screening of $3 \times 10^{5}$ plaques. Eighteen of the phage contained sequences complementary to the 3 -untranslated region of $\mathrm{C} / \mathrm{EBP} \alpha$ cDNA when screened at high stringency. Reasoning that these phage contained C/EBP $\alpha$-encoding inserts, we discarded them. The remaining 12 clones fell into two classes and were subsequently found to be de- rived from two different genes. One class contained 11 clones with the longest insert covering $1 \mathrm{~kb}$, and the other contained a single clone with an insert covering 0.6 $\mathrm{kb}$. DNA sequence analysis of the inserts from the two classes revealed that both encoded bZIP proteins highly similar to $\mathrm{C} / \mathrm{EBP} \alpha$ (Fig. 1A,B). To simplify the nomenclature for this and future studies, the C/EBP-related proteins have been termed according to their chronological order of isolation. According to this nomenclature, the original $\mathrm{C} / \mathrm{EBP}$ is now called $\mathrm{C} / \mathrm{EBP} \alpha$, the group that contained 11 clones is called C/EBP $\beta$, and the single clone is referred to as C/EBPS (see Discussion).

A somewhat unusual feature of the $c / e b p \alpha$ gene is that it is free of intervening sequences (Landschulz et al. 1988a). Judging from the close sequence relatedness among $c / e b p \beta, c / e b p \delta$, and $c / e b p \alpha$, we reasoned that the newly isolated genes might also be intron free. Genomic DNA fragments corresponding to $c / e b p \beta$ and c/ebp $\delta$ were isolated and sequenced. Large open reading frames, which contained the bZIP domain, were found in the genomic fragments corresponding to $c / e b p \beta$ and $c / e b p \delta$ The open reading frame of the gene encoding C/EBP $\beta$ was observed to encode a hypothetical protein of 296 amino acids with a predicted molecular mass of $31.3 \mathrm{kD}$. The c/ebp $\delta$ gene encoded a hypothetical protein of 268 amino acids with a predicted molecular mass of $28.6 \mathrm{kD}$.

The nucleotide sequences and conceptually translated amino acid sequences of both C/EBP $\beta$ and C/EBP $\delta$ are shown in Figure 1. TATAAA homologies were observed within 100 nucleotides upstream from the putative translation initiation codon of both proteins, suggesting that each gene might be transcribed into a simple, intron-free mRNA. To test this possibility we identified the precise points of transcription initiation on each gene. Oligonucleotides complementary to sequences located just $3^{\prime}$ to the putative translation initiation codon of both C/EBP isoforms were synthesized (Fig. 1A,B), radiolabeled, and used in primer extension assays (McKnight et al. 1981) with poly(A) ${ }^{+}$RNA isolated from differentiating 3T3-L1 cells. The lengths of the primer extension products shown in Figure 1C, are consistent with initiation of $c / e b p \beta$ gene at a cluster of sites 54-58 bp upstream of the putative translation initiation codon and initiation of $c / e b p \delta$ gene at $38 \mathrm{bp}$ upstream from the putative translation start site. In both cases, the inferred initiation sites are located downstream of TATAAA homologies.

The deduced amino acid sequences of C/EBP $\beta$ and $\mathrm{C} / \mathrm{EBP} \delta$ were compared with that of $\mathrm{C} / \mathrm{EBP} \alpha$ with a computer program that identifies regions of amino acid sequence similarity (Corpet 1988). As shown in Figure 2, the carboxy-terminal regions of the three proteins, which contain the bZIP domain, are highly conserved. The basic regions of the three proteins share 21 of 24 identical amino acids (enclosed by a solid line in Fig. 2). The amino acid sequence similarity between C/EBP $\beta$ and $\mathrm{C} / \mathrm{EBP} \alpha$ extended farther toward their respective amino termini, consisting of 8 identical residues within the next 11 positions. In contrast, the sequence of C/EBPS diverged in this region and included 2 proline 
C/EBP

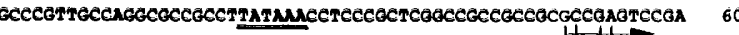

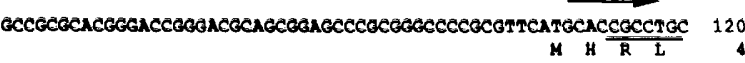

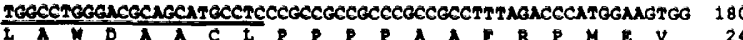
COAACTTCTACTACGAGCCCGACTGCCTGCCCTACGGGGCCAAGGCGECCCGCGCCGCGC 240

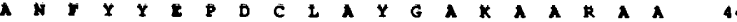
CGCGCGCCCCCGCCGCCGACCCGGCCATTGGCGACCACGACCGCGCCATCGACTICAGCC 300 R A A A P A I t R I D S CCTACCTGGACCCECTCGCGeCCGCCGCGGACTTCeCCeCGCCCGCeCCCCGCACCACG 360 Y L ACTTCCTCTCCGACCTCTTCGCCGACGACTACGGCGCCANGCCGAGCMAGMAGCCGGCCG 420

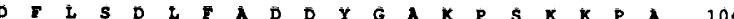
ACTACCGTTACGTGAGCCTCGECCGCGCGGGCGCCAAGGCCGCGCCGCCCGCCTGCTTCC 480 D Y G Y V S L G R A G A K A A P P A C F 124 CGCCGCCGCCTCCCGCGGCGCTCNAGCCGGAGCCGCGCTTCGNACCCOCGGACTGCANGC 540 P P P P A A L K A E P G F : P D C X 14 GCGCGGACGACSCGCCCGCCATGGCGCCCGGTTTCCCGTTCGCCCTOCOCOCCTACCTCG 600

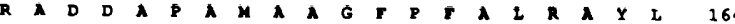
GCTACCAGGCGACGCCGAGCGGCAGCAGCGGCAGCCTGTCCACGTCGTCGTCGTCCAGCC 660 $G Y^{\prime} A^{\prime} T$ S G S S G S L S T S S S S CGCCCGGCACGCCGAGCCCCGCCGACGCCAAGGCCGCGCCCGCCGCCTGCTTCGCGGGGC 720 P P G I P S P A CGCСGGCCСGCCCGCCNAGGCCNAGGCCNAGMGACGGTGGACNAGCTGAGCGACGAGT 780

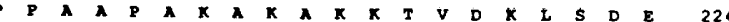
ACAAGATGCGGCGCGAGCGCAACAACATCGCGGTGCGCMMGAGCCGCGACAMGGCCAMGA

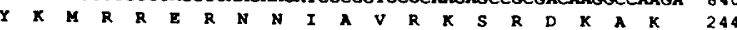
TGCGCAACCTGGAGACGCAGCACAAGGTGCTGGAGCTGACGGCGGAGAACGAGCGGCTGC 900

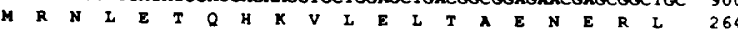
AGMGMAGGTGGAGCAGCTGTCGCGAGAGCTCAGCACCCTGCGGANCTTGTTCAAGCAGC 960

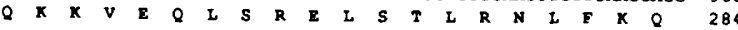
TGCCCGAGCCGCTGCTGGCCTCGGCGGGCEACTGCTAGCGCGGCGCGGTGGCGTGGGGGG 1020 L P I P L L A S A G H C 296

CGCCCCGGCCACCGTGCGCCCTGCCCCGCGCGCTCCGGCCCCGCGCGCGCGCCCGGACCA 1080

CCGTGCGTGCCCTGCGCGCACCTGCACCTGCACCGAGGGANACCGCGGCACACCGCGG 1140 GCACGCGCGGCGCACGCACCTGCACAGCGCACCGGGTTTCGGGACTTGATGCMATCCGGA 1200 TCAACGTGGCTGAGCGCGTGTGGACACGGGACTACGCMCACACGTGTAACTGTCTAGC 1260 CGGCCCCTGAGTMATCACCTTMAMATGTTCCTGCGGGGTTGTTGATGTTTTTGGTTTTG 1320 TTITTGTTTTTGTTTGTTTTGTTTTTTTTTTTGGTCTAATAATTITITTGTATTATA 1380 TMNAMATTCTATTTCTATGAGMANGAGGCGTATGTATATTTGAGAACCTTTTCCGTT 1440 TCGAGCATTAAAGTGAAGACATTTTAATMACTTTTTTGGGAGMTGTTTAMAAGCCAMA 1500

Figure 1. Nucleotide sequences and conceptually translated protein sequences of C/EBP $\beta$ and C/EBP $\delta$. The nucleotide sequence of $c / e b p \beta$ gene is shown in $A$, and that of $c / e b p \delta$ is shown in $B$. TATAAA homologies, putative polyadenylation signals, and sequences complementary to the oligonucleotides used for primer extension analyses $(C)$ are underlined. The deduced amino acid sequences are shown in the single-letter code beneath the corresponding codons of the nucleotide sequence. Arrows indicate the sites of transcription initiation as deduced by primer extension $(C) .(C)$ An autoradiographic exposure of a polyacrylamide gel used to size primer extension products. The locations of primer complementarity are shown in $A$ and $B$. Poly $(\mathrm{A})^{+}$RNA isolated from differentiating 3T3-LI cells was annealed to synthetic oligonucleotides that had been end-labeled with $\left[\gamma^{32} \mathrm{P}\right]$ ATP and polynucleotide kinase. Annealed oligonucleotides served as primers for cDNA synthesis by reverse transcriptase. Lengths of extension products were determined by their mobility relative to radiolabeled $M s p I$ fragments derived from pBR322 (indicated in nucleotides to the left of the autoradiogram). Sequence of $\mathrm{C} / \mathrm{EBP} \delta$ has been submitted to GenBank.

\section{C/FBP}

GACCTCGATCCCTGTTCCECCTTTGCTATGTCTGMAGCCGTCCTGCTTTGCGCGTGTCGG 60 GECCNATCCAGATTTTCATTTCGCTCCAGGCTTGGACGGCTMAGTAGGTCCAMACCGCA 120 CNMCNGGNAGAGGGNGGCNAGAGTGCGGGCAGNGGGCGGGTCGTTCCCAGCAGCAC 180 COCAOTCCCTCOCCGCRCCORCTCCGACCCACTGGGGCCGGGGCGGGCGTGCGCGTCAGC 240

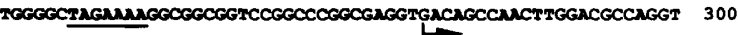

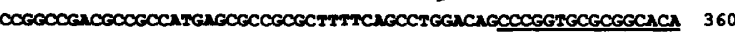
I A I S D S P R G T 15

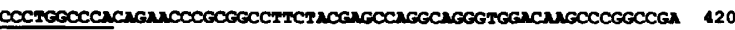
P P T I P A Y Y I P G R V D X P G R 35

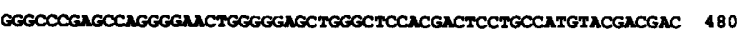
G P I P G I L G I I G S T T P A M Y D D GAGAGCGCCATCGACTTCAGCGCCTACATTGACTCCATGGCCGCCGTGCCCACCCTAGAG 540 $\begin{array}{llllllllllllllllllll}\text { I S A } & \text { I } & \text { D } & \text { T } & \text { S } & \text { A } & \text { Y } & \text { I } & \text { D } & \text { S } & \text { M A A } & \text { A } & \text { P } & \text { I } & \text { E } & 75\end{array}$

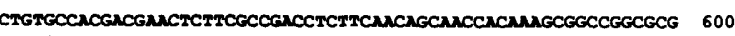
I C I D I I A D I I S A B A A A 95 GGCGCCCTGANCCTCCTCCNGGGCGGCCCTNCGCGNCCCCCGGGTGTGGGGTCTGTCGCT 660

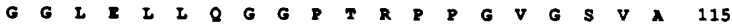

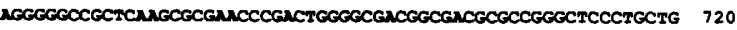
$\begin{array}{llllllllllllllllllll}\text { R G P I } & X & R & \text { I } & \text { P } & \text { D } & \text { W } & G & \text { D } & \text { G } & \text { D } & \text { A } & \text { P } & \text { G } & \text { S } & \text { L } & \text { L } & 135\end{array}$ CCGGCGCANGTGGCGGTGTECGCGCNGACAGTGGTGAGCTTGGCGGCCGCGGCTCAGCCC 780

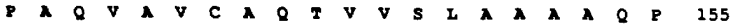
ACTCCACCCACTTCGCCGGACCCTCCRCGACGCAGCCCGGGGCCGNGCCTCGCGCCCGGC $\begin{array}{lllllllllllllllllllll}\text { I } & \text { P } & \text { P } & \text { I } & \text { S } & \text { P } & \text { I } & \text { P } & \text { P } & \text { R } & G & \text { S } & \text { P } & \text { G } & \text { P } & \text { S } & \text { L } & \text { A } & \text { P } & \text { G } & 175\end{array}$ ACAGTCOGAGAMAGGGCGCGGCCNAGAGGGGTCOGGACCGCGGCAGCCCGGAGTACCGG 900

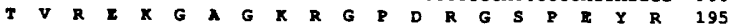

CAGCGGCGCGNGCGCANCNACATCGCTGTGCGCNMGAGCCGCGACAAGGCCAAGCGCCGC 960 $\begin{array}{lllllllllllllllllllll}Q & R & R & E & R & N & N & I & A & Y & R & K & S & R & D & K & A & K & R & 215\end{array}$ AACCAGGAGATGCAGCAGAAGCTGGTGGAGTTGTCGGCCGAGAACGAGAAGCTGCATCAG 1020

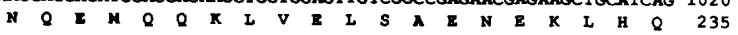
CGCGTGGAGCAGCTCACCCGGGACCTGGCTGGCCTCCGGCAGTTCTTCAAAAAACTGCCC 1080 $\begin{array}{lllllllllllllllllllll}R & V & \text { I } & Q & \text { L } & \text { T } & R & D & \text { L } & \text { A } & G & \text { L } & \text { R } & Q & \text { F } & \text { F } & \text { K } & \text { K } & \text { L } & \text { P } & 255\end{array}$ ACCCCCCTTTCCTGCCGCCCACCGGCGCCGACTGCCGGTAACGCGCGGCGTGGGCCTTT 1140 $\begin{array}{llllllllllllllllll}S & \text { P } & \text { P } & \text { F } & \text { L } & \text { P } & \text { P } & \text { T } & G & A & D & C & R & * & 268\end{array}$

GAGACTCTGAACGACCTATACCTCAGACCCCGACAGCGGGGAGCAGACGCCGCCCGAATC 1200 GCTAGTTTCTTTGGGACCTGCGAGCGACAGGMGCTGCAGCTTGGGCACTGGACTGCGAG 1260 AGAAGCTATATTAATCTITCCCCTTAAATTATTTTTTATAATGGTAGCATTTTCTACGTC 1320

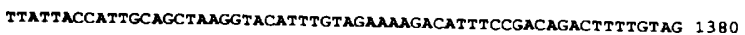
ATALGAGAAGAGACTGCGCATGCTTTTTATATTCATTTTTACAGTATTTGTAAGAATAA 1440 GAATAAGMATAMAGAMGCATTTAAATCGCAMAMANAA 1478

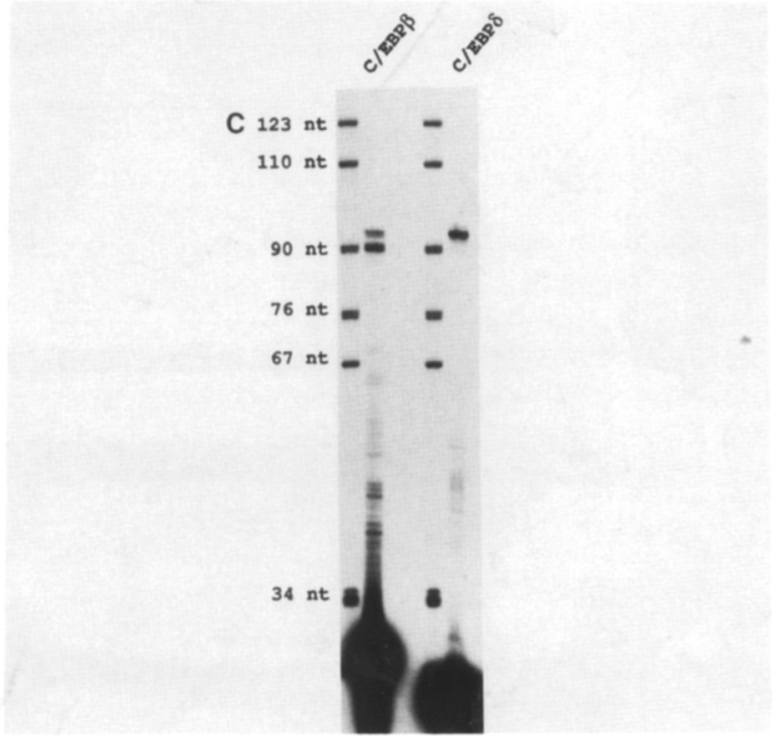


and 4 glycine residues that probably interrupt the $\alpha$-helical structure predicted to occur in this region of $\mathrm{C} / \mathrm{EBP} \alpha$ and C/EBP $\beta$. This observation may be noteworthy, as previous experiments demonstrated that mutations in the corresponding region of $\mathrm{C} / \mathrm{EBP} \alpha$ resulted in a notable decrease in DNA-binding affinity (Landschulz et al. 1989).

All three C/EBP-related proteins contain a heptad repeat of leucines in perfect register relative to the location of the highly conserved basic region (Fig. 2). The heptad array of leucine residues is diagnostic of a dimerization interface termed the leucine zipper. In addition to the leucine repeats and their invariant location with respect to the basic region, the three proteins contain highly related residues at the $i+4$ position relative to each leucine. When projected onto an idealized $\alpha$-helix, the amino acids at this $i+4$ position are aligned on the same helical face with the leucine residues forming a
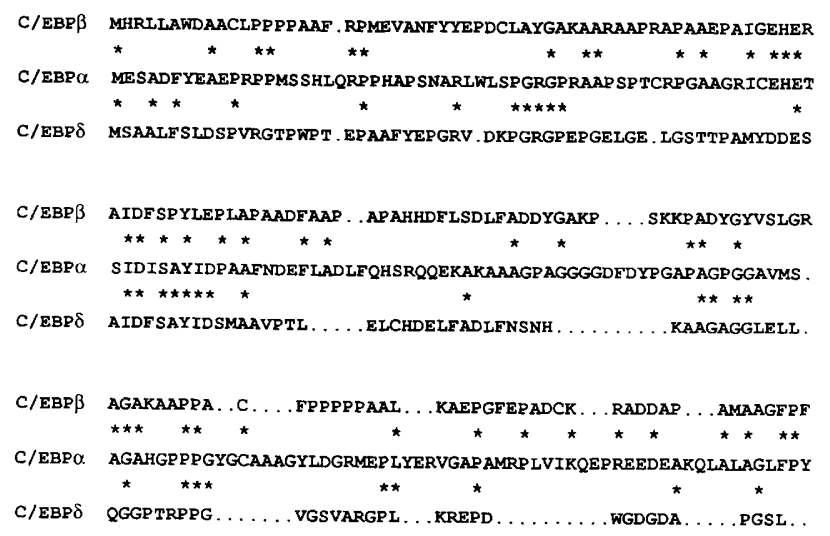

C/EBP $\beta$ ALRA ........... YLGYQATPSGSSG.SLSTSSSSSPPGT. PSPADAKAAPA C/EBP $\alpha$ QPPPPPPPPHPHASPAHLAAPHLQFQIAHCGQTTMHLQPGHPTPPPTPVPSPHPAPAMGA C/EBP $\delta \ldots \ldots \ldots \ldots \ldots \ldots \ldots$ IPAQVAVCAQTVVSIAAAAQPTPPT $\ldots$. SPEPPRGSPG
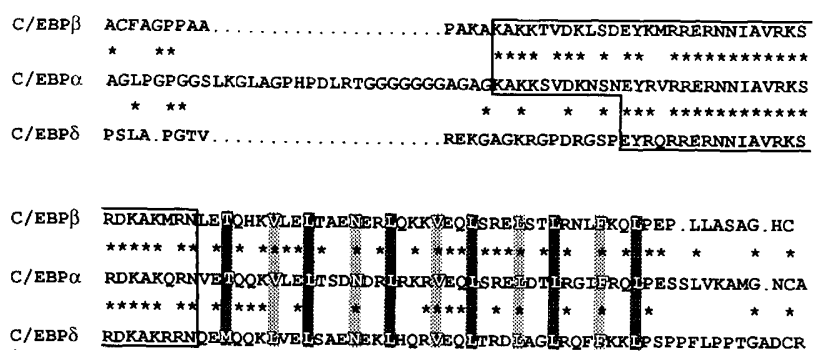

Figure 2. Amino acid sequence comparison of $\mathrm{C} / \mathrm{EBP} \alpha$, $\mathrm{C} / \mathrm{EBP} \beta$, and C/EBPS. Amino acid sequences are displayed such that $\mathrm{C} / \mathrm{EBP} \beta$ (top) and C/EBPS (bottom) are compared with $\mathrm{C} / \mathrm{EBP} \alpha$ (middle). Positions of identity are marked with an asterisk $\left({ }^{*}\right)$. The basic region of each protein, which is thought to mediate direct contact with DNA, is enclosed by a solid line. Leucines organized in a heptad repeat are identified by dark shading. The $i+4$ positions /relative to the heptad repeat of leucines|, which are thought to contribute to the hydrophobic dimer interface, are indicated by light shading. The sequences were aligned to reveal regions of similarity using a multiple sequence alignment program (Corpet 1988). hydrophobic dimerization interface (Landschulz et al. $1988 \mathrm{~b}$ ). With one exception, all three C/EBP isoforms contain identical amino acids at the $i+4$ positions of each repeat. The single exception to this $i+4$ identity occurs in the most amino-terminal heptad repeat of C/EBPס, which contains a leucine residue rather than the valine present in $\mathrm{C} / \mathrm{EBP} \alpha$ and $\mathrm{C} / \mathrm{EBP} \beta$ (Fig. 2). Leucine is a reasonably conservative substitution for valine and is unlikely to alter substantially the amphipathic, $\alpha$-helical property of this region.

The amino acid sequence similarities shared by $\mathrm{C} / \mathrm{EBP} \alpha, \mathrm{C} / \mathrm{EBP} \beta$, and $\mathrm{C} / \mathrm{EBP} \delta$ provide strong clues as to the functions of the two newly identified proteins. They are probably transcription factors that bind to DNA as dimers. However, as Figure 2 clearly shows, the aminoterminal two-thirds of the proteins are largely unrelated at the level of primary amino acid sequence. This raises the possibility that each C/EBP isoform might be capable of mediating different regulatory processes.

\section{Comparison of DNA-binding properties among $C / E B P$ isoforms}

Given the exceptional relatedness in the basic region of $\mathrm{C} / \mathrm{EBP} \alpha, \mathrm{C} / \mathrm{EBP} \beta$, and $\mathrm{C} / \mathrm{EBP} \delta$, it was anticipated that they might bind similar DNA substrates. To test this possibility each protein was purified and studied in DNA-binding assays. DNA fragments that encoded the bZIP domain of C/EBP $\beta$ and C/EBPס were cloned into T7 expression vectors (Studier and Moffatt 1986; Rosenberg et al. 1987). Each polypeptide was overexpressed in Escherichia coli and purified to homogeneity according to methods described previously (Shuman et al. 1990). The purified proteins were tested for their ability to bind to a high-affinity $\mathrm{C} / \mathrm{EBP} \alpha$ target sequence in gel-shift assays (Fried and Crothers 1981). Both C/EBP $\beta$ and C/EBPS were capable of shifting the mobility of the radioactively labeled DNA probe in the presence of an excess amount of nonspecific competitor DNA (data not shown).

To assess and compare DNA-binding affinities of the three C/EBP proteins, we performed saturating binding assays in which a constant amount of protein was titrated with increasing amounts of a radiolabeled oligonucleotide containing an optimal C/EBP-binding sequence (Vinson et al. 1989). After incubation at $24^{\circ} \mathrm{C}$ for $20 \mathrm{~min}$, the binding mixtures were subjected to polyacrylamide gel electrophoresis to separate protein-bound oligonucleotides from free ones. An autoradiographic image was used to locate the bound and free oligonucleotides (Fig. 3, top). The corresponding gel segments were then excised and measured for radioactivity by scintillation spectroscopy. Such assays revealed that with variable rates, the amount of bound probe approached saturation within the range of input in all three sets of assays, using polypeptides corresponding to $\mathrm{C} / \mathrm{EBP} \alpha$, C/EBP $\beta$, and C/EBP (Fig. 3, middle). The data were subjected to Scatchard analysis (Scatchard 1949), generating the plots shown in the bottom panel of Figure 3. Such analyses allowed calculation of dissociation constants $\left(K_{\mathrm{d}}\right)$ for each protein and revealed a hierarchy of binding 
affinities for the synthetic oligonucleotide wherein $\mathrm{C} / \mathrm{EBP} \beta>\mathrm{C} / \mathrm{EBP} \alpha>\mathrm{C} / \mathrm{EBP} \delta$ (Fig. 3). Similar results were obtained in repeated experiments. Possible explanations for the observed differences in DNA-binding affinity are outlined in the Discussion.

\section{Gene-activating properties of the three C/EBP isoforms}

The confirmation that C/EBP $\beta$ and C/EBP $\delta$ bind with relatively high affinity to the same DNA sequence as $\mathrm{C} / \mathrm{EBP} \alpha$ prompted us to test whether these two proteins might be capable of activating transcription. Previous studies have demonstrated that $\mathrm{C} / \mathrm{EBP} \alpha$ can trans-activate the promoter of the serum albumin gene in transiently transfected hepatoma cells (Friedman et al. 1989). This same assay was used to test the potential of C/EBP $\beta$ and C/EBP $\delta$ to activate transcription. The coding sequences of both genes were cloned into a plasmid vector
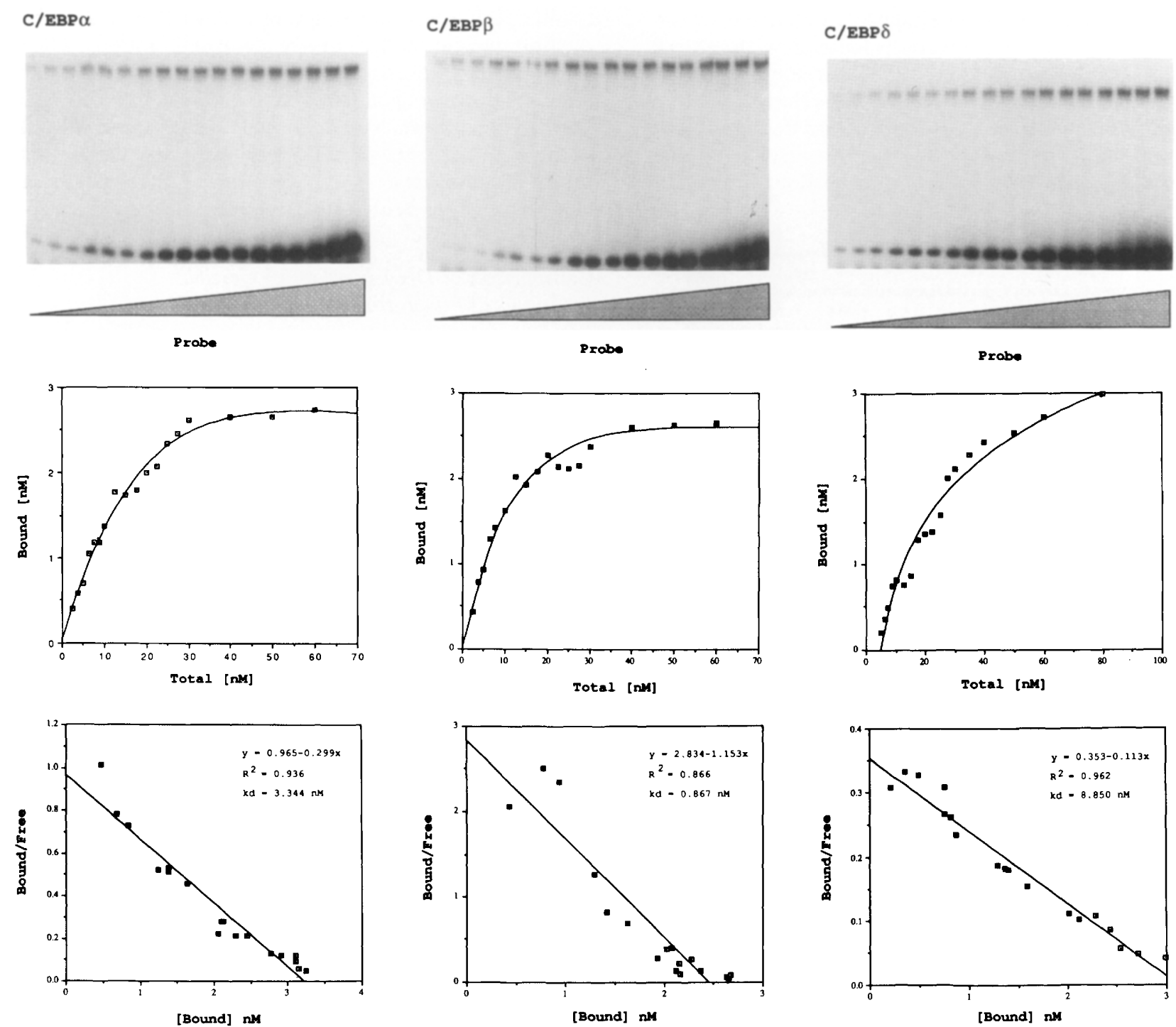

Figure 3. Measurements of relative DNA-binding affinities of C/EBP isoforms. Dissociation constant measurements for each C/EBP isoform were determined from quantitative evaluation of gel-shift assays visualized in the top panel of each column. (Top) Autoradiographic images identifying positions of bound and free probe. From left to right, each panel shows multiple lanes corresponding to binding reactions that contained a constant amount of purified polypeptide and increasing amounts of radiolabeled oligonucleotide containing a high-affinity C/EBP $\alpha$-binding site (Shuman et al. 1990). Gel slices corresponding to the positions of bound and free forms of probe were excised and quantitated for radioactivity by scintillation spectroscopy. The amount of bound probe was plotted as a function of total input, as shown in each of the three middle panels. In the lower input range, the amount of bound probe increased rapidly with increased probe input. At higher input levels, however, the increase in bound probe was observed to reach a plateau level, apparently reflecting binding saturation. This apparent saturation was more evident in assays of C/EBP $\alpha$ and C/EBP $\beta$ than of C/EBPס. (Bottom) Scatchard plots (Scatchard 1949) of saturation curves shown in middle panels. When plotted by the method of Scatchard (ratio of bound and free vs. bound) a linear correlation was observed between the two variables, allowing calculation of dissociation constants $\left(K_{\mathrm{d}}\right)$ wherein $K_{\mathrm{d}}=-1 /$ slope. 
in which expression of the particular $c / e b p$ gene was under the control of the murine sarcoma virus long terminal repeat (Graves et al. 1985). Such expression vectors were transfected into HepG2 cells along with a reporter construct containing the promoter of the mouse albumin gene linked to the herpes simplex virus (HSV) thymidine kinase ( $t k$ ) gene (Zaret et al. 1988). The ability of the albumin promoter to direct transcription of the $t k$ gene in the absence or presence of the various C/EBP isoforms was measured by a primer extension assay with RNA isolated from transiently transfected cells. Primer extension products were separated by gel electrophoresis and visualized by autoradiography. The results presented in Figure 4A show that hepatoma cells transfected with the reporter construct alone failed to express the $t k$ mRNA. In contrast, transcription of the $t k$ gene became evident when the reporter plasmid was cotransfected with expression vectors encoding each of the three $\mathrm{C} / \mathrm{EBP}$ isoforms. According to this admittedly crude assay, the trans-activation potentials of the three C/EBP proteins differed less than threefold.
Because the three isoforms of $\mathrm{C} / \mathrm{EBP}$ are capable of binding to the same DNA sequence (see Fig. 3), it was assumed that the observed transcriptional activation of the albumin promoter occurred through the same cisregulatory sequence. To test this hypothesis, the reporter plasmid containing the native albumin promoter was replaced with one containing a site-directed mutation in the C/EBP $\alpha$-binding site (Friedman et al. 1989). The mutated reporter plasmid was not expressed at a significant level in response to any of the three C/EBP isoforms. The residual level of activation of the mutant plasmid might result from protein bound to low-affinity sites within the albumin promoter (Lichtsteiner et al. 1987).

Western blots were conducted on protein extracts prepared from transiently transfected cells to monitor the level of expression of the various C/EBP isoforms. Cell cultures were transfected in duplicate with those used for the primer extension assays described above. After SDS-gel separation, proteins were transferred to nitrocellulose and probed with specific antisera raised against synthetic peptides unique to the individual C/EBP iso-

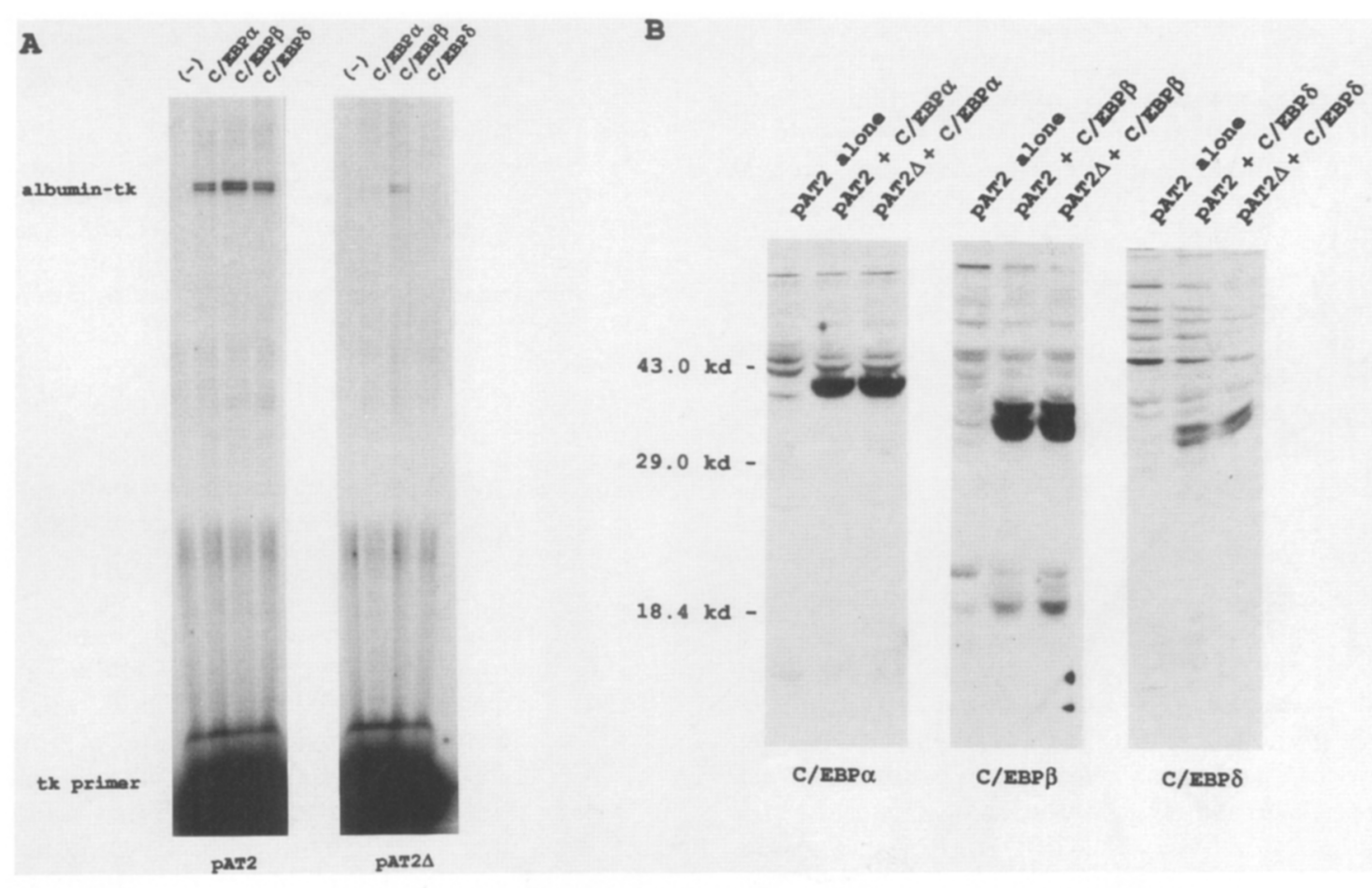

Figure 4. Trans-activation of the promoter of the serum albumin gene by three isoforms of C/EBP. The gene-activating potentials of C/EBP $\beta$ and C/EBP $\delta$ were compared with C/EBP $\alpha$ with a transient transfection assay described previously (Friedman et al. 1989). Duplicate cultures of HepG2 cells were exposed to calcium phosphate precipitates containing $6 \mu \mathrm{g}$ of an albumin/tk reporter plasmid (pAT2) and $12 \mu \mathrm{g}$ of one of three MSV-C/EBP expression plasmids (see Materials and methods). Two days after transfection one culture plate from each experiment was harvested for extraction of RNA and one plate was harvested for solubilization of total cell protein. Identical experiments were performed with a reporter plasmid (pAT2 2 ) that was mutated at the high-affinity C/EBP-binding site within the albumin promoter (Friedman et al. 1989). (A) Autoradiographic exposures of sequencing gels that were used to size primer extension products. (Left) Products obtained with the pAT2 reporter plasmid; (right) products obtained with pAT2 $\Delta$. Locations of $t k$ primer and extension products are designated. Left-most lanes of each experiment show primer extension reactions resulting from RNA prepared from HepG2 cells that had been transfected with the reporter plasmid alone. $(B)$ Autoradiographic exposures of Western blots used to monitor expression of the three isoforms of C/EBP in transiently transfected HepG2 cells. Antisera used for Western blots are indicated below each autoradiographic exposure. Numbers shown to the left indicate positions of migration of molecular mass markers. 
forms (see Materials and methods). Multiple immunoreactive bands were visible on each filter. By the criteria of molecular size and transfection dependency, however, most bands could be identified as nonspecific, cross-reactive material. Transfection-dependent bands were readily detectable in the gel lanes containing proteins from cells transfected with C/EBP-encoding expression vectors. The molecular masses of these proteins, suggested by their rates of migration relative to molecular mass marker proteins, agreed well with the polypeptide sizes predicated by conceptual translation of the cloned genes (see Fig. 1). The results outlined in this section argue that the products of $c / e b p \beta$ and $c / e b p \delta$ genes, like $\mathrm{C} / \mathrm{EBP} \alpha$, can function as gene-activating proteins.

\section{Formation of heterodimers between C/EBP isoforms}

The observation that the $c / e b p \beta$ and $c / e b p \delta$ genes encode transcription factors closely related to $\mathrm{C} / \mathrm{EBP} \alpha$ raised the possibility that these factors might form mixed dimers. Substantial evidence has accumulated indicating that $\mathrm{C} / \mathrm{EBP} \alpha$ binds to DNA as an obligate dimer and that dimerization is mediated through the leucine zipper. The high degree of amino acid sequence similarity among the three C/EBP isoforms in their respective leucine zippers, particularly along the hydrophobic dimer interface, strongly indicated that they would be capable of forming heterodimers. Moreover, the fact that cDNAs encoding all three isoforms were isolated from a single cell type (adipocytes) suggested that all isoforms might be present simultaneously in a single cell. In an attempt to determine the generality of this observation, we examined the mRNA expression profile of the isoforms in various mouse tissues.

The results of Northern blot assays, shown in Figure 5, demonstrated that the three genes are expressed in a common set of tissues (although the expression levels vary significantly). Similar to previous findings (Birkenmeier et al. 1989), C/EBP $\alpha$ mRNA was found at abundant levels in liver and fat, and at low but detectable levels in intestinal and lung tissues. C/EBP $\beta$ was detected in all tissues examined with the exception of brain and testes. Relative to C/EBP $\alpha, C / E B P \beta$ mRNA levels were found to be quite high in intestine and lung. C/EBPס mRNA was most abundant in lung, intestinal, and adipose tissues. Such observations indicate that if a tissue expresses one type of C/EBP mRNA at a considerable level, it is likely to express at least one other type. Likewise, several tissues, such as brain and testes, fail to express any of the three mRNA types at a considerable level. Assuming that mRNA levels reflect protein expression levels, it can be anticipated that the various isoforms are coexpressed in several different cell types.

The results outlined in the previous paragraph prompted experiments that would test for the formation of mixed dimers between the various C/EBP isoforms. Using the strategy developed by Hope and Struhl (1987), we performed gel-shift assays to test for heterotypic mixing of C/EBP isoform. Polypeptides of unique molecular size, corresponding to each C/EBP isoform, were ex-

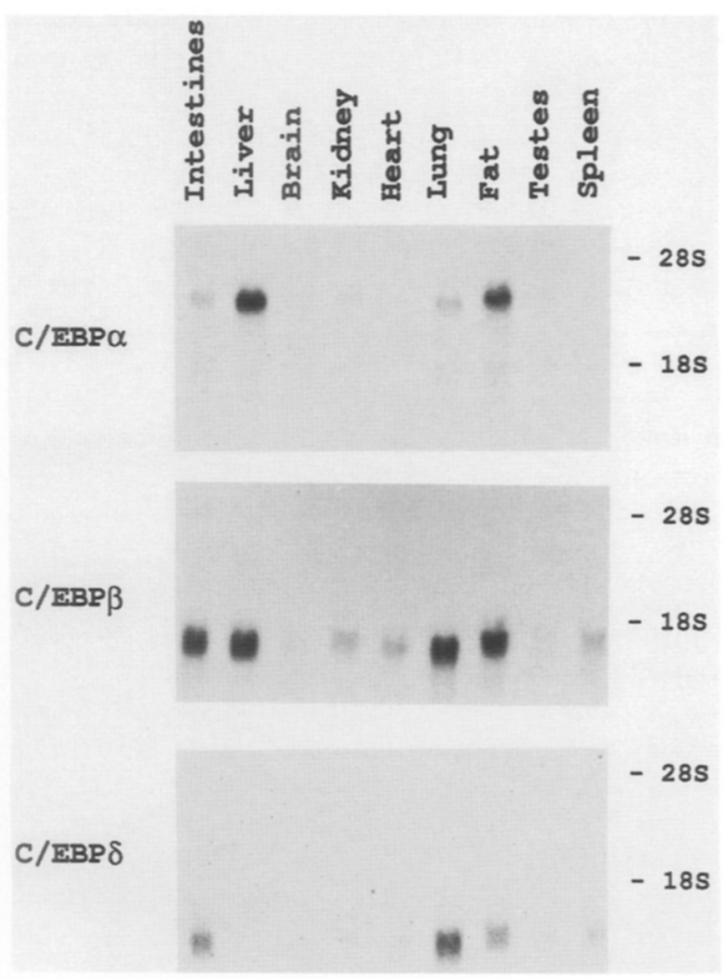

Figure 5. Northern blot assays of mRNA accumulation of C/EBP isoforms in various mouse tissues. Total RNA was extracted from indicated tissues of adult mice. Fifteen micrograms of RNA was loaded in each lane of a denaturing agarose gel. Ethidium bromide staining was used to ensure that each gel lane was loaded with an equivalent concentration of intact RNA (not shown). Sized RNAs were transferred to a nitrocellulose membrane that was successively probed with radioactive DNA corresponding to C/EBP $\alpha, \mathrm{C} / \mathrm{EBP} \beta$, and C/EBP8. Autoradiographic images were obtained after each hybridization. Probe was removed between successive hybridization reactions by exposing the filter to distilled water at $100^{\circ} \mathrm{C}$ for $5 \mathrm{~min}$. The positions of $28 \mathrm{~S}$ and $18 \mathrm{~S}$ rRNA are indicated at right.

pressed in E. coli and purified to homogeneity (see Materials and methods). Two forms of $\mathrm{C} / \mathrm{EBP} \alpha$, a 20- and a $10-\mathrm{kD}$ form, were prepared and used as a positive control for dimer formation. Equal molar amounts of the 20- and $10-\mathrm{kD}$ polypeptides were incubated with a radiolabeled DNA fragment containing a high-affinity $\mathrm{C} / \mathrm{EBP} \alpha$-binding site. After allowing protein-DNA complexes to form, the samples were subject to electrophoresis and the positions of migration of the DNA probe were visualized by autoradiography. Figure 6 shows that the 20and $10-\mathrm{kD} C / \mathrm{EBP} \alpha$ polypeptides formed three complexes that migrated slower than the free DNA. The fastest migrating complex comigrated with the complex formed when probe was mixed with the $10-\mathrm{kD}$ species alone. The slowest migrating complex comigrated with that formed with the $20-\mathrm{kD}$ species. A third complex was observed between the inferred 20- and 10-kD homodimer complexes. The complex of intermediate mobility was interpreted to represent a heterodimeric complex composed of one 20- and one 10-kD subunit. 


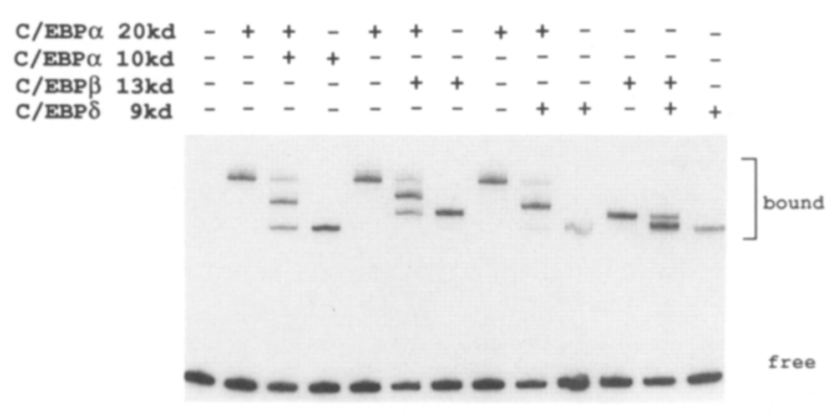

Figure 6. Assay for heterodimer formation between C/EBP isoforms. Purified polypeptides corresponding to each C/EBP isoform, and mixtures thereof, were exposed to a radiolabeled DNA fragment containing a high-affinity C/EBP-binding site. Protein-DNA mixes were electrophoresed on a nondenaturing polyacrylamide gel (see Materials and methods). After electrophoresis the gel was dried and exposed to $\mathrm{x}$-ray film. Bound and free forms of the radiolabeled probe DNA are indicated. Polypeptides included in each binding reaction are indicated $1+1$ above each gel lane.

The ratio of the three $\mathrm{C} / \mathrm{EBP} \alpha$ complexes was $\sim 1: 2: 1$ corresponding, presumably, to homodimer 20 $\mathrm{kD}$, heterodimer $20 \mathrm{kD} / 10 \mathrm{kD}$, and homodimer $10 \mathrm{kD}$. The observed ratio of $1: 2: 1$ is precisely that expected if heterodimers form as readily as homodimers and have equivalent binding affinity for the target DNA. This result was anticipated as the two $\mathrm{C} / \mathrm{EBP} \alpha$ molecules bear identical DNA-contact regions and dimerization interfaces. Figure 6 also shows the results obtained when the radiolabeled DNA probe was incubated with $\mathrm{C} / \mathrm{EBP} \beta$ or $\mathrm{C} / \mathrm{EBP} \delta$ polypeptides alone, in combination with one another, or in combination with the $20-\mathrm{kD}$ form of $\mathrm{C} / \mathrm{EBP} \alpha$. When tested alone, each of the polypeptides formed a complex of unique mobility. When any combination of two isoforms was mixed, three complexes were detected. Two of the three complexes corresponded to the sizes of the parental homodimers, and one complex exhibited an intermediate size. The size difference between $\mathrm{C} / \mathrm{EBP} \beta$ and $\mathrm{C} / \mathrm{EBP} \delta$ peptides was too small to allow a clear resolution of the three complexes in the autoradiogram that is shown in Figure 6. However, careful examination of a lighter autoradiographic exposure revealed two species in the thick lower band.

In each reaction where different polypeptides were mixed, the ratio of the complexes appeared to be $\sim 1: 2: 1$. However, one exception to this trend was observed. The presumed $\mathrm{C} / \mathrm{EBP} \alpha / \mathrm{C} / \mathrm{EBP} \delta$ heterodimer complex appeared to constitute a considerably higher proportion than expected. Possible explanations for this observation are addressed in the Discussion.

\section{Regulation of $C / E B P \beta$ and $C / E B P \delta$ expression during adipocyte differentiation}

Having established an initial characterization of $\mathrm{C} / \mathrm{EBP} \beta$ and C/EBP $\delta$, we undertook experiments designed to ask whether these transcription factors, as with $\mathrm{C} / \mathrm{EBP} \alpha$, might help to regulate adipose conversion. As an initial goal we set out to determine the temporal patterns of expression of C/EBP $\beta$ and C/EBP $\delta$ during adipocyte differentiation. 3T3-L1 adipoblasts were induced to differentiate by using previously established methods (Student et al. 1980). Cells were grown to confluence in growth medium containing calf serum and shifted to differentiation medium containing fetal calf serum, insulin, dexmethasone, and methylisobutylxanthine. Two days later, dexmethasone and methylisobutylxanthine were removed. The progress of differentiation was monitored by measuring the accumulation of RNAs encoding adipocyte-specific proteins (Bemlohr et al. 1984; Dobson et al. 1987). Total RNA was harvested from cells immediately before and at daily intervals after the switch to differentiation medium. The Northern blot images depicted in Figure 7 show that expression of the mRNA encoding fatty acid-binding protein 422 was first detectable on day 3 and rose to a plateau level 7 days after the switch to differentiation medium. Transcription of the gene encoding glycerol-3-phosphate dehydrogenase (GPDH) was initially detected at day 5 and reached a plateau level by the seventh day of the differentiation program. The expression of these adipocyte-specific genes was accompanied by overt changes in cell morphology, including the accumulation of fat droplets (not shown).

The RNA samples collected before and during differentiation were also probed with radioactively labeled cDNA fragments corresponding to each of the C/EBPrelated genes. Consistent with earlier studies (Birkenmeier et al. 1989), the mRNA encoding for C/EBP $\alpha$ was first detectable on day 2 , increased gradually through day 6 , and remained at an unchanged level thereafter. The accumulation profiles of the C/EBP $\beta$ and C/EBP mRNAs differed significantly from those of $\mathrm{C} / \mathrm{EBP} \alpha$ mRNA. The mRNAs encoding C/EBP $\beta$ and C/EBP $\delta$ were detectable in undifferentiated adipoblasts. Furthermore, the mRNA levels of these two genes increased slightly during the hormone-rich period early during the differentiation program. Expression of C/EBP $\beta$ mRNA was reduced during the latter half of the differentiation program, yet remained readily detectable. C/EBPS mRNA accumulation, on the other hand, was observed to be reduced dramatically during the final days of adipocyte differentiation.

To test whether changes in mRNA levels of C/EBP isoforms were reflected by changes in the levels of their encoded proteins, SDS-solubilized extracts were prepared from 3T3-L1 cells that had been differentiated in parallel with those used for Northern blot analysis. Solubilized proteins were separated by SDS-PAGE gel electrophoresis and analyzed by Western blot assays with antisera specific to each of the C/EBP isoforms (see Materials and methods|. The results of such studies, shown in Figure 8, indicated that the pattern of C/EBP $\alpha$ expression was similar to that of its encoding mRNA. The $\mathrm{C} / \mathrm{EBP} \alpha$ polypeptide was undetectable in undifferentiated cells, first appeared at the fourth day of the program, and increased in abundance throughout the remaining 


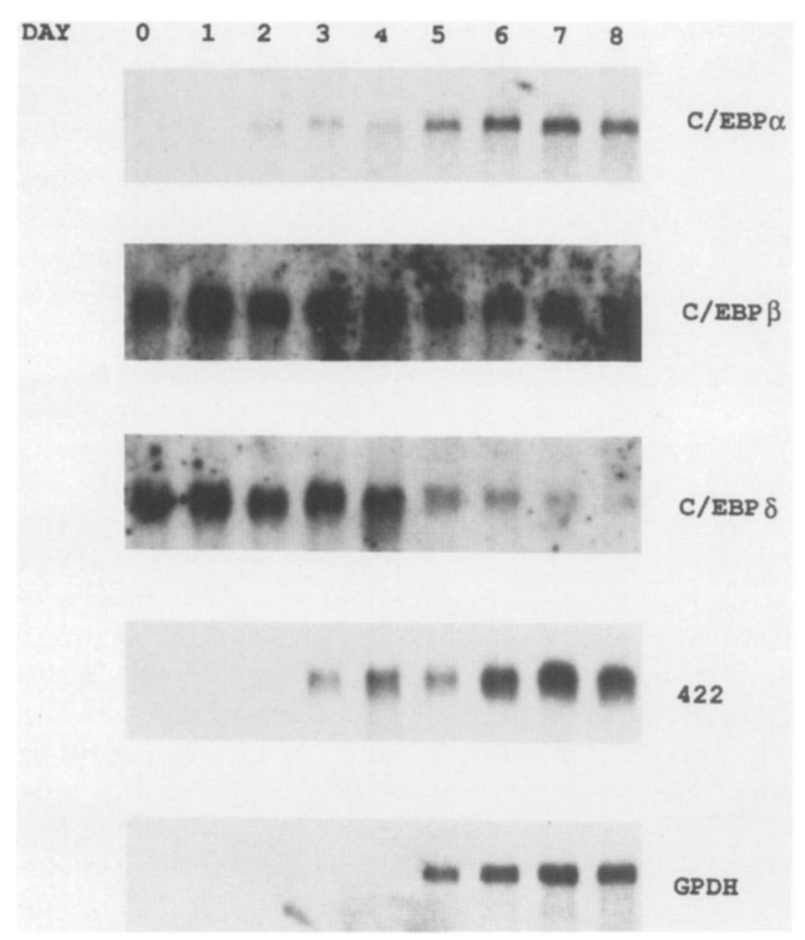

Figure 7. Measurements of accumulation of specific mRNAs during adipocyte differentiation. Total RNA was harvested from 3T3-Ll cells before (day 0) and at daily intervals after (days 1-8) the switch from growth medium to differentiation medium (see Materials and methods). Ten-microgram aliquots of each RNA were size separated on five equivalent agarose electrophoresis gels. RNA was transferred to nitrocellulose and probed under stringent hybridization conditions with radioactive DNAs corresponding to the three $\mathrm{C} / \mathrm{EBP}$ isoforms $/ \mathrm{C} / \mathrm{EBP} \alpha$, C/EBP $\beta$, and C/EBP 8 ) and two genes whose products are expressed in terminally differentiated adipocytes (fatty acid-binding protein 422 and glycerol-3-phosphate dehydrogenase). Each mRNA migrated with an apparent size (not shown) consistent with that of previous reports (Bemlohr et al. 1984; Dobson et al. 1987; Landschulz et al. 1988a; Chang et al. 1990; see also Fig. 5).

days of differentiation. The expression profiles of the $\mathrm{C} / \mathrm{EBP} \beta$ and C/EBP $\delta$ polypeptides differed somewhat from the profiles of their encoding mRNA. Specifically, both $\mathrm{C} / \mathrm{EBP} \beta$ and C/EBP $\delta$ exhibited accentuated accumulation upon hormone treatment relative to their mRNAs. That is, although both mRNAs were observed to increase slightly in abundance between days 0 and 1 , the protein levels increased much more substantially during this period. Such findings raise the possibility that the expression of C/EBP $\beta$ and C/EBP 8 proteins is regulated at both transcriptional and post-transcriptional levels.

The expression profiles of the three C/EBP-related proteins are plotted as a function of adipocyte differentiation in Figure 9 (top). The times of addition and removal of adipogenic hormones are also indicated. In Figure 9 (bottom), the expression profiles of the adipocyte-specific mRNA are similarly displayed. Such analyses show that concerted changes in C/EBP $\beta$ and C/EBP $\delta$ expres- sion precede the onset of $\mathrm{C} / \mathrm{EBP} \alpha$ expression as well as the accumulation of adipocyte-specific mRNAs. This temporal correlation, combined with previous studies showing that activation of $\mathrm{C} / \mathrm{EBP} \alpha$ alone is insufficient to drive adipose conversion (Umek et al. 1991), raised the possibility that $\mathrm{C} / \mathrm{EBP} \beta$ and $\mathrm{C} / \mathrm{EBP} \delta$ regulate early events required for adipocyte differentiation.

The expression profiles of C/EBP $\beta$ and C/EBP $\delta$ also appeared to correlate with the presentation and withdrawal of adipogenic hormones, suggesting that these transcription factors might play a role in mediating cellular responses to such hormones. Following this lead we tested whether transcription of the c/ebp $\beta$ and c/ebp $\delta$ genes might be regulated directly by adipogenic hormones (insulin, dexmethasone, and methylisobutylxanthine). 3T3-L1 adipoblasts were treated individually with insulin, dexmethasone, or methylisobutylxanthine in the presence of cycloheximide. Cycloheximide blocks protein synthesis and can therefore be used to discriminate between direct and indirect action of hormones on the process of gene expression. After $4 \mathrm{hr}$ of hormone treatment, RNA was prepared and analyzed by Northern blotting to determine the expression pattern of each C/EBP-related gene. The results shown in Figure 10 revealed an increase in C/EBP $\beta$ mRNA in response to methylisobutylxanthine and an increase in C/EBPS mRNA in response to dexmethasone. The expression of the $\mathrm{C} / \mathrm{EBP} \alpha$ gene was undetectable in the presence of any of the three hormones, consistent with previous results

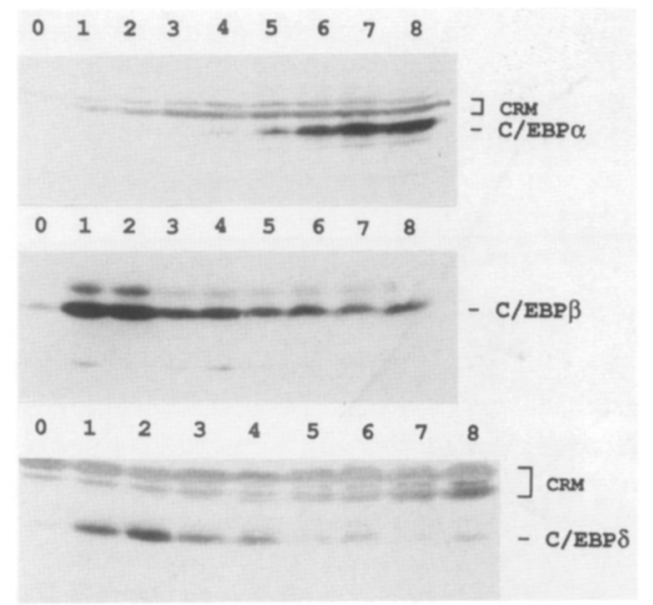

Figure 8. Measurements of accumulation of various C/EBPrelated polypeptides during adipocyte differentiation. Cultures of 3T3-Ll cells were programmed to differentiate in parallel with those evaluated in Figure 7 . Total cellular protein was solubilized before (day 0) and at daily intervals after (days 1-8) the switch from growth medium to differentiation medium (see Materials and methods|. Proteins were electrophoresed on a denaturing polyacrylamide gel, transferred to nitrocellulose, and probed by Western blotting with antibodies specific to each C/EBP isoform. The positions of migration of each isoform are indicated at the right of each autoradiographic exposure. Crossreacting materials (CRM) observed in samples probed with antibodies specific to C/EBP $\alpha$ and C/EBP $\delta$ are indicated. 

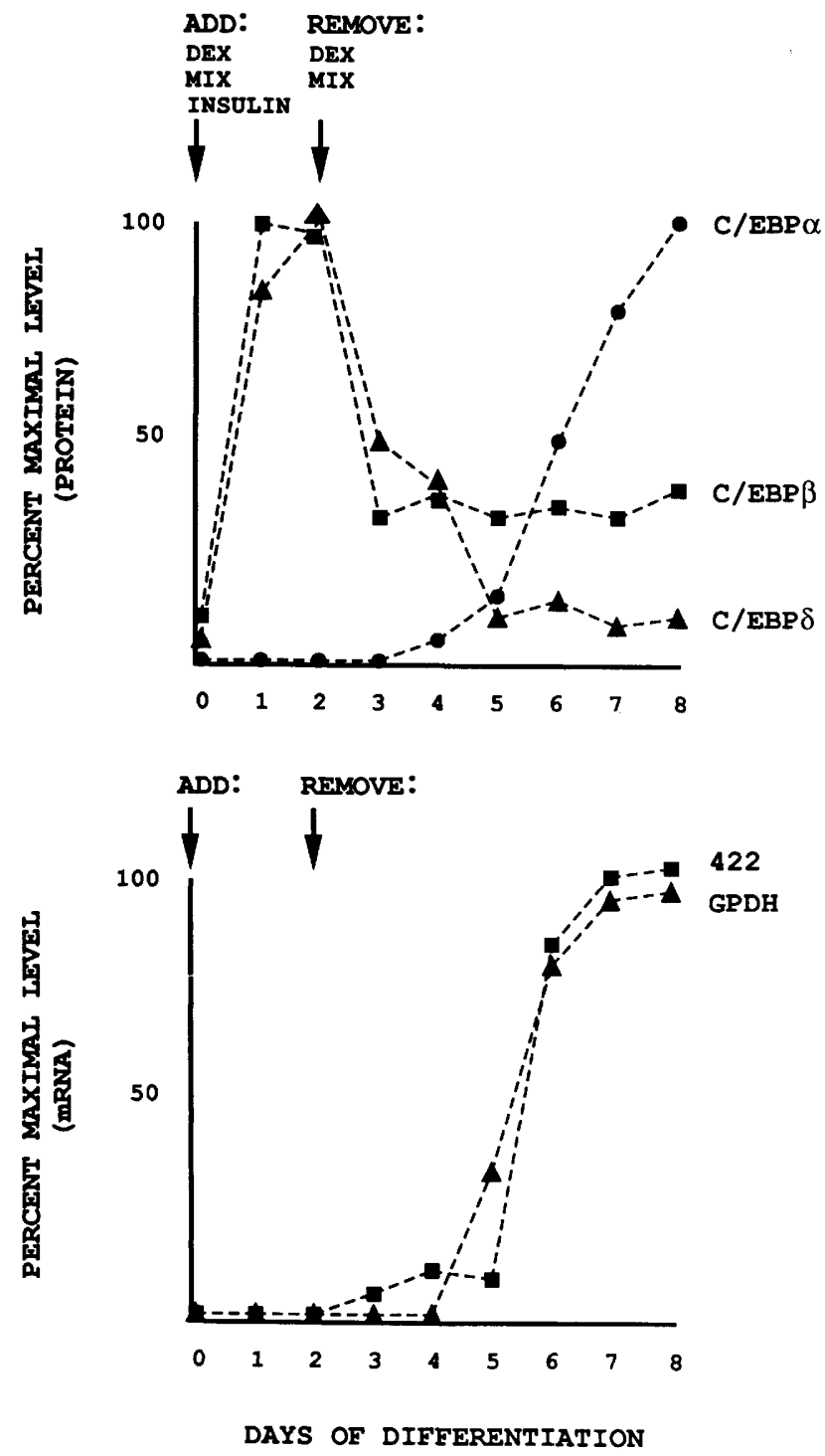

Figure 9. Graphic representation of the temporal expression profiles of C/EBP isoforms and adipocyte-specific mRNAs during terminal differentiation. (Top) Accumulation of C/EBP isoforms as measured by Western blotting. The graph plots the percent maximal concentration of each protein (ordinate) as a function of the temporal order of differentiation (abscissa). (Bottom) A similarly arranged graph plotting the accumulation of 422 and GPDH mRNA. Data points were obtained by densitometric scanning of the autoradiograms shown in Figs. 7 and 8. The times of addition (day 0) and removal (day 2) of adipogenic hormones [dexamethasone (DEX), methylisobutylxanthine (MIX), insulin] are indicated at top.

demonstrating that $\mathrm{C} / \mathrm{EBP} \alpha \mathrm{mRNA}$ is not expressed in proliferating adipoblasts.

\section{Discussion}

C/EBP $\alpha$ is one of many proteins that contains a bZIP DNA-binding domain. DNA-binding proteins of this class are characterized by the juxtaposition of a region rich in basic amino acids to a region containing a heptad repeat of hydrophobic amino acids (often leucines). The two regions have been proposed to occur in a contiguous $\alpha$-helical conformation. The $\alpha$-helix of the leucine repeat region is believed to intertwine with the analogous region of a second bZIP protein, forming a dimer. The basic regions of the paired subunits are believed to interact with each half of a dyad-symmetric DNA-binding site, forming a "scissors grip" around the DNA substrate (Landschulz et al. 1988b, 1989; O'Shea et al. 1989; Vinson et al. 1989).

Inspection of the primary amino acid sequences of bZIP proteins has shown that certain members of this family of proteins are more closely related than others. For example, groupings of Fos-related proteins (Van Beveren et al. 1983; Cohen and Curran 1988; Zerial et al. 1989; Nishina et al. 1990), Jun-related proteins (Maki et al. 1987; Ryder and Nathans 1988; Hirai et al. 1989; Ryder et al. 1989), and ATF/CREB-related proteins (Hoeffler et al. 1988; Lin and Green 1988; Hai et al. 1989; Berkowitz and Gilman 1990; Ivashkiv et al. 1990) have been described. Differences in amino acid sequence in the bZIP region of these proteins influence two of their known functions-DNA-binding specificity and dimerization specificity. For example, the basic regions of $\mathrm{C} / \mathrm{EBP} \alpha$ and GCN4, a bZIP protein that regulates genes encoding enzymes necessary for de novo amino acid biosynthesis in budding yeast (Struhl 1989), have been

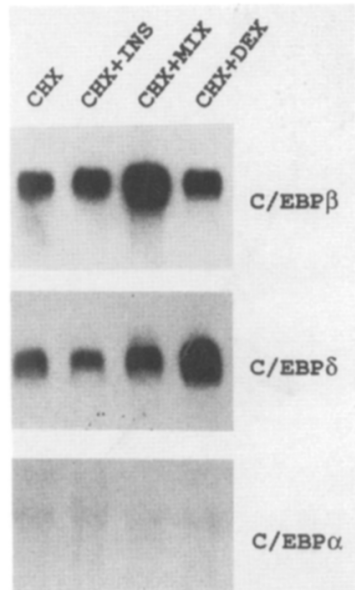

Figure 10. Evidence that genes encoding C/EBP $\beta$ and C/EBPS are primary targets of adipogenic hormones. Undifferentiated adipoblast cells were preincubated with cycloheximide for $1 \mathrm{hr}$ before challenge with individual hormones. Cells were incubated for $4 \mathrm{hr}$ after addition of hormones. Total RNA was extracted from cells exposed to cycloheximide alone ( $\mathrm{CHX})$, or in combination with individual adipogenic hormones; insulin $(\mathrm{CHX}+\mathrm{INS})$, methylisobutylxanthine $(\mathrm{CHX}+\mathrm{MIX})$, and dexamethasone $(\mathrm{CHX}+\mathrm{DEX})$. RNA samples were loaded in triplicate onto a denaturing electrophoresis gel, size-separated, transferred to nitrocellulose, and probed with radiolabeled DNA frag. ments corresponding to $\mathrm{C} / \mathrm{EBP} \beta$ (top), C/EBP (middle), and $\mathrm{C} / \mathrm{EBP} \alpha$ (bottom). Sizes of hybridizing RNA bands (not shown) were consistent with prior measurements (see Fig. 5). 
shown to dictate DNA-binding specificity (Agre et al. 1989). Likewise, the leucine repeat segment of bZIP proteins has been found to dictate dimerization specificity. Fos-related proteins dimerize preferentially with Jun-related proteins (Halazonetis et al. 1988; Kouzarides and Ziff 1988; Rauscher et al. 1988; Sassone-Corsi et al. 1988; Smeal et al. 1989), yet neither Fos- nor Jun-related proteins will cross-dimerize with $\mathrm{C} / \mathrm{EBP} \alpha$ (Y. Nakabeppu and W. Landschulz, unpubl.).

Several genes encoding proteins bearing a high degree of amino acid sequence similarity to the bZIP region of $\mathrm{C} / \mathrm{EBP} \alpha$ have recently been isolated and characterized. The first C/EBP-related gene to be characterized encodes a protein termed NF-IL6 (Akira et al. 1990). The gene encoding NF-IL6 was cloned by DNA ligand-mediated screening of an expression library prepared from human glioblastoma cDNA. Recombinant DNA clones corresponding to the rat and mouse homologs of NF-IL6 were subsequently isolated. The protein products of these genes have been variously termed LAP, IL-6DBP, and AGP/EBP according to the perceived function of the protein (Chang et al. 1990; Descombes et al. 1990; Poli et al. 1990|. Another closely related gene, encoding a protein termed Ig/EBP-1, has been isolated by DNA ligand-mediated screening of cDNAs prepared from cultured mouse fibroblasts (Roman et al. 1990). Ig/EBP-1 binds avidly to the $E$ site of the immunoglobulin heavy-chain gene enhancer. NF-IL6 (as well the homologous proteins from rat and mouse) and Ig/EBP-1 bind DNA with a specificity similar to C/EBP $\alpha$ (Akira et al. 1990; Chang et al. 1990; Descombes et al. 1990; Poli et al. 1990; Roman et al. 1990), and both proteins have been shown to be capable of cross-dimerization with C/EBP $\alpha$ (Descombes et al. 1990; Poli et al. 1990; Roman et al. 1990).

Here we report the isolation of genes encoding two $\mathrm{C} / \mathrm{EBP}$-related proteins. One of the genes we have studied, $c / e b p \beta$, is the mouse homolog of NF-IL6. The other gene characterized in this report, c/ebp $\delta$, is distinct from other known C/EBP-related genes. Judging by the number of C/EBP-related genes isolated in the past year, the size of the family can be expected to expand. In an attempt to clarify the confusing nomenclature that has evolved for proteins encoded by C/EBP-related genes, we propose that proteins capable of cross-dimerization with C/EBP be designated by C/EBP followed by a Greek letter indicative of their chronological order of characterization. According to this system, the first protein to be characterized by study of its encoding gene, originally termed C/EBP, will now be called C/EBP $\alpha$. Similarly, NF-IL6 will be termed C/EBP $\beta$, Ig/EBP-1 will be termed $\mathrm{C} / \mathrm{EBP} \gamma$, and the new family member characterized in this study will be termed C/EBPS.

The critical criterion for assigning a bZIP protein to the C/EBP family is dimerization specificity. If proteins cross-dimerize readily in vitro, they may also crossdimerize in vivo. If so, their functional properties may be integrated into a restricted "pod" of interacting proteins. Although in vivo cross-mixing of $\mathrm{C} / \mathrm{EBP}$ isoforms has yet to be conclusively demonstrated, several observations outlined in this report may be relevant to this issue.
First, cDNAs encoding three forms of C/EBP have been isolated from the same cell type (differentiating adipocytes). Second, a positive correlation was observed in the distribution of tissues that express the three C/EBP isoforms characterized in this study. Thus, we anticipate that certain cell types will simultaneously express more than one form of $\mathrm{C} / \mathrm{EBP}$, thereby offering the opportunity for the formation of heterodimeric complexes.

Given the expectation that different C/EBPs will cross-dimerize in vivo, we have referred to the variant proteins as "isoforms." This term emphasizes the similarity between C/EBP variants. It is important, however, to point out significant differences in the C/EBP isoforms characterized to date. First, they are encoded by different genes. Indeed, $\mathrm{C} / \mathrm{EBP} \alpha, \mathrm{C} / \mathrm{EBP} \beta$, and $\mathrm{C} / \mathrm{EBP} \delta$ are located on entirely different mouse chromosomes (E. Birkenmeier, Z. Cao, and S. McKnight, unpubl.|. Second, the amino acid sequences of the amino-terminal twothirds of each of the C/EBP isoforms are not detectably related (see Fig. 2; Roman et al. 1990). The amino-terminal two-thirds of $\mathrm{C} / \mathrm{EBP} \alpha$ contains functional determinants important for its role in gene activation (Friedman and McKnight 1990; Pei and Shih 1991) and in mitotic growth arrest (Umek et al. 1991). We anticipate that the amino-terminal regions of C/EBP $\beta$ and C/EBP $\delta$ will also perform important regulatory functions, perhaps distinct from that of C/EBP $\alpha$. For example, C/EBP $\beta$ (NF-IL6) has been implicated in cellular response to interleukin 6 (Poli et al. 1990). It is possible that the amino-terminal region of $\mathrm{C} / \mathrm{EBP} \beta$ is responsible for mediating the regulatory effects of interleukin 6 .

The heterodimerization between different C/EBP isoforms provides an additional level of complexity in addressing the functional properties of this group of transcription factors. As yet, we have not developed assays for the function of C/EBP heterodimers. Each of the three protein forms characterized in this study is capable of avid interaction with DNA, and heteromeric dimers also bind DNA avidly. When C/EBP $\alpha$ and C/EBP $\delta$ were mixed, the presumed heterodimeric complex was observed at a higher than expected ratio relative to the two homomeric complexes (see Fig. 6). We have not resolved the molecular basis for this somewhat unexpected observation. However, if bona fide, this observation might indicate that a cell harboring equal amounts of both isoforms would contain relatively small amounts of homodimeric $\mathrm{C} / \mathrm{EBP} \alpha$ or $\mathrm{C} / \mathrm{EBP} \delta$. Taking such speculation one step further, one might imagine that certain functions of $\mathrm{C} / \mathrm{EBP} \alpha$ might require the protein in a homodimeric form (e.g., during the late phase of adipocyte differentiation). If so, constitutive expression of C/EBP $\delta$ might impede the formation of C/EBP $\alpha$ homodimers and thereby subvert their hypothetical function.

Quantitative DNA-binding assays of the various C/EBP isoforms revealed a hierarchy of avidities wherein $\mathrm{C} / \mathrm{EBP} \beta$ bound DNA more tightly than $\mathrm{C} / \mathrm{EBP} \alpha$, which, in turn, bound DNA more tightly than C/EBPS. We do not know whether these differences in binding affinity are meaningful, particularly given that they were observed with fragments derived from the various C/EBP 
isoforms. However, it is perhaps understandable that C/EBPס binds DNA less avidly than the other two isoforms. C/EBPS lacks a stretch of basic amino acids common to $C / E B P \alpha$ and $C / E B P \beta$ (see Fig. 2). A variant form of C/EBP $\alpha$ lacking this amino-terminal extension of the "basic region" has been found to bind DNA severalfold less avidly than the native polypeptide (Landschulz et al. 1989).

We hope that expanded knowledge of the specific roles played by different C/EBP-related proteins will eventually provide a means of addressing the putative functions of heterodimeric complexes. In this regard we pay particular interest to the temporally regulated patterns of C/EBP isoform expression during adipogenesis. Observations made thus far point to an important role for $\mathrm{C} / \mathrm{EBP} \alpha$ in terminal differentiation of adipocytes. The temporal pattern of $\mathrm{C} / \mathrm{EBP} \alpha$ expression correlates with the induction of adipocyte-specific gene expression and the cessation of mitotic growth (Birkenmeier et al. 1989). Premature expression of C/EBP $\alpha$ causes adipoblasts to arrest mitotic growth, yet does not lead directly to adipocyte differentiation (Umek et al. 1991). The latter observation suggests that $\mathrm{C} / \mathrm{EBP} \alpha$ may not be the immediate target regulated by adipogenic hormones. Consistent with this interpretation, the onset of $\mathrm{C} / \mathrm{EBP} \alpha$ expression is delayed relative to the time of hormonal challenge (Figs. 7 and 8; Birkenmeier et al. 1989), and hormonal stimulation does not activate transcription from the gene encoding $\mathrm{C} / \mathrm{EBP} \alpha$ in the presence of a protein synthesis inhibitor (Fig. 10).

In contrast to $C / E B P \alpha$, the regulated patterns of expression of C/EBP $\beta$ and C/EBP $\delta$ might implicate these isoforms as mediators of adipoblast response to adipogenic hormones. The expression levels of both C/EBP $\beta$ and C/EBP $\delta$ are increased dramatically during the time of hormonal stimulation (see Fig. 8). Furthermore, the C/EBP $\beta$ - and C/EBP $\delta$-encoding genes are activated directly by adipogenic hormones (Fig. 10). Finally, the levels of these two proteins decline after the removal of hormones, before the overt onset of $\mathrm{C} / \mathrm{EBP} \alpha$ expression.

The sequential expression of $\mathrm{C} / \mathrm{EBP}$ isoforms raises the possibility that C/EBP $\beta$ and C/EBP $\delta$ are responsible for the induction of $\mathrm{C} / \mathrm{EBP} \alpha$. Consistent with this possibility, Lane and co-workers have discovered an avid C/EBP-binding site in the promoter of the gene encoding $\mathrm{C} / \mathrm{EBP} \alpha$ (Christy et al. 1991). Moreover, these investigators have found that extracts prepared from differentiating adipocytes contain proteins, in addition to $\mathrm{C} / \mathrm{EBP} \alpha$, that bind to the C/EBP-binding site located within the $\mathrm{C} / \mathrm{EBP} \alpha$ promoter. Even if C/EBP $\beta$ and C/EBP $\delta$ do serve to induce expression of $\mathrm{C} / \mathrm{EBP} \alpha$, such a simple regulatory cascade cannot fully explain the process of adipocyte differentiation. If the only role of the "early" C/EBP isoforms (C/EBP $\beta$ and C/EBP $\delta$ ) was to activate the expression of the "late" form (C/EBPo), then premature expression of $\mathrm{C} / \mathrm{EBP} \alpha$ should lead directly to terminal differentiation-which it does not (Umek et al. 1991).

We have provided no direct evidence indicative of a functional role for C/EBP $\beta$ and C/EBP $\delta$ during adipogenesis. We also do not exclude the involvement of regula- tory proteins other than those characterized in this study. We do, however, find the temporal expression patterns of the three C/EBP isoforms sufficiently compelling to warrant further study and anticipate that efforts to discern and assign unique properties to each isoform will help elucidate potential roles for these transcription factors during terminal cell differentiation.

\section{Materials and methods \\ Cloning of $\mathrm{c} / \mathrm{ebp} \beta$ and $\mathrm{c} / \mathrm{ebp} \delta$ genes}

Poly $(\mathrm{A})^{+}$RNA was selected from total RNA extracted from differentiating $3 \mathrm{~T} 3-\mathrm{L} 1$ cells. A cDNA library was constructed using the $A Z A P$ unidirectional cloning kit (Stratagene). The library was screened at reduced hybridization stringency (Lee 1990) with a 150-bp DNA probe corresponding to the bZIP domain of C/EBP $\alpha$. Thirty bacteriophage, obtained from a screen of $3 \times 10^{5}$ plaques, survived tertiary screening. Eighteen of the recombinants tested positive when probed with a $1-\mathrm{kb}$ HindIIIEcoRI DNA fragment corresponding to the 3 '-untranslated region of the C/EBP $\alpha$ mRNA (Landschulz et al. 1988a). These clones were judged to contain cDNA copies of the C/EBP $\alpha$ mRNA and were discarded. Bluescript plasmids containing cDNA inserts were excised from the remaining 12 bacteriophage isolates following recommended procedures (Stratagene). Eleven of these plasmids yielded a positive hybridization signal when challenged at high stringency with the cDNA insert derived from clone 5 . The clone 5 cDNA insert was the largest of the 12 and was later designated $c / e b p \beta$. Clone 18, which did not cross-hybridize to the clone 5 insert, was later designated $c / e b p \delta$. Both $c / e b p \beta$ and $c / e b p \beta$ were sequenced by the dideoxynucleotide chain-termination method with a commercial sequencing kit (Pharmacia).

Genomic DNA clones corresponding to $c / e b p \beta$ and $c / e b p \delta$ were also isolated and sequenced. The genomic clones were found to contain DNA sequences colinear with their respective partial cDNAs. Sequence analysis of the genomic clones also revealed that each contained an intron-free open reading frame. Furthermore, TATAAA homologies were found in close proximity $5^{\prime}$ to the presumptive translation initiation codon, and putative polyadenylation sites were found in close proximity $3^{\prime}$ to the translation termination codons.

\section{Overexpression and purification of $C / E B P \beta$ and $C / E B P \delta$ polypeptides}

Polypeptides corresponding to the bZIP domains of C/EBP $\beta$ and C/EBPS were overexpressed in $E$. coli with an expression system directed by bacteriophage T7 RNA polymerase (Studier and Moffatt 1986). Partial cDNA sequences of $c / e b p \beta$ and $c / e b p \delta$ were cloned into a pET3 vector (Rosenberg et al. 1987) with the correct open reading frame. The resulting plasmids express a $13-\mathrm{kD}$ C/EBP $\beta$ polypeptide and a 9-kD C/EBP $\delta$ polypeptide. Each polypeptide contains the entire DNA-binding domain. The C/EBP $\beta$ and C/EBP $\delta$ polypeptides were expressed in the BL21 strain of $E$. coli and purified to homogeneity with column chromatographic techniques as described earlier (Shuman et al. 1990).

Trans-activation of the albumin promoter by $C / E B P \beta$ and $C / E B P \delta$

The vector used to express full length of C/EBP $\beta$ and C/EBP $\delta$ in eukaryotic cells was the same as was used to express C/EBP $\alpha$ 
(Friedman et al. 1989). Protein-encoding genomic DNA sequences of $c / e b p \beta$ and $c / e b p \delta$ were cloned into the vector between the Moloney murine sarcoma virus long terminal repeat (Graves et al. 1985) and the transcription termination/polyadenylation signals of the HSV $t k$ gene (McKnight 1980).

Transfection of hepatoma cells was performed according to the calcium phosphate method (Graham and Van der Eb 1973). The reporter plasmid used to test for trans-activation by the various C/EBP isoforms was pAT2 (Zaret et al. 1988), which consists of the promoter of the mouse serum albumin gene fused to the mRNA-coding segment of the HSV tk gene. Procedures for cell culture, transient transfection, RNA preparation, and primer extension have been described previously (Friedman et al. 1989).

\section{Gel mobility-shift assays}

The DNA probe used in gel mobility-shift assays (Fried and Crothers 1981) was a 136-bp BgIII-EcoRI fragment of the HSV $t k$ gene modified to contain a high-affinity C/EBP $\alpha$-binding site (Vinson et al. 1989). The probe DNA was radiolabeled with $\left[\alpha^{32} \mathrm{P}\right] \mathrm{dCTP}$ and $\left[\alpha^{32} \mathrm{P}\right] \mathrm{dATP}$ with a fill-in reaction. Polypeptides corresponding to the $20-$ and $10-\mathrm{kD}$ forms of C/EBP $\alpha$ (Shuman et al. 1990), the 13-kD form of $\mathrm{C} / \mathrm{EBP} \beta$, and the $9-\mathrm{kD}$ form of $\mathrm{C} / \mathrm{EBP} \delta$ were added to binding reactions either alone or as mixtures prepared at a final concentration of $0.5 \mathrm{fm}$. Binding reactions $(20 \mu \mathrm{l})$ consisted of $10 \mathrm{~mm}$ Tris- $\mathrm{HCl}(\mathrm{pH} 7.5), 2 \mathrm{~mm}$ DTT, $50 \mathrm{~mm} \mathrm{KCl}, 10 \%$ (vol/vol) glycerol, $0.5 \mu \mathrm{g}$ of poly[d(I-C)] (Sigma), and $1 \mathrm{mg} / \mathrm{ml}$ of bovine serum albumin (Boehringer Mannheim Biochemicals|. Before addition of probe DNA, binding reactions were incubated at room temperature for $10 \mathrm{~min}$ to allow equilibration of polypeptide dimers. Probe DNA was added to a final concentration of 1-2 fM, and reactions were incubated for 20 min at room temperature before being loaded onto a $5 \%$ polyacrylamide gel containing $0.5 \times$ TBE buffer and $5 \%$ glycerol. Gels were electrophoresed at a constant rate of $300 \mathrm{~V}$ at $4^{\circ} \mathrm{C}$ for $5 \mathrm{hr}$, dried, and exposed to $\mathrm{x}$-ray film without an intensifying screen.

Saturation-binding assays were carried out under the conditions described above with a double-stranded oligonucleotide probe containing a high-affinity $\mathrm{C} / \mathrm{EBP} \alpha$-binding site (Shuman et al. 1990). The DNA probe consisted of the self-complimentary, dyad-symmetric sequence 5 '-TGCAGATTGCGCAATCTGCA-3' and was labeled at the $5^{\prime}$ termini with $\left[\gamma^{32} \mathrm{P}\right] \mathrm{ATP}$ and polynucleotide kinase. After gel electrophoresis and autoradiography, radioactive bands corresponding to free and proteinbound DNA probe were excised and quantitated by counting in a scintillation spectrophotometer.

\section{Induction of 3T3-L1 cell differentiation}

Culture and differentiation induction of 3T3-L1 cells was performed as described previously (Student et al. 1980). Briefly, cells were propagated to confluency in $90-\mathrm{mm}$ plastic plates in Dulbecco's modified Eagle medium (DMEM) containing 10\% fetal calf serum. On differentiation day 0 , cells were fed with DMEM supplemented with $10 \%$ fetal calf serum, $0.5 \mathrm{mM}$ methylisobutylxanthine, $10 \mu \mathrm{g} / \mathrm{ml}$ of insulin, and $10^{-6} \mathrm{M}$ dexamethasone. Cells were changed to culture medium lacking methylisobutylxanthine and dexamethasone 2 days later (differentiation day 2) and harvested at daily intervals for analysis of protein and mRNA accumulation.

\section{Northern blot analysis}

Total RNA was extracted from tissues of adult mice (C57BL6; Jackson Laboratories) or from differentiating 3T3-L1 cells ac- cording to the procedures of Chomczynski and Sacchi (1987). Fifteen-microgram amounts of each RNA sample were electrophoresed through denaturing formaldehyde-agarose gels (Lehrach et al. 1977), transferred to GeneScreen membranes (NEN), and probed with radiolabeled DNA fragments corresponding to the three C/EBP isoforms.

Preparation of rabbit antisera specific to $C / E B P \beta$ and $C / E B P \delta$

Synthetic peptides corresponding to the carboxy-terminal sequences of C/EBP $3\left(\mathrm{NH}_{2}\right.$-LRNLFKQLPEPLLASAGHC-COOH) and C/EBP $\delta$ ( $\mathrm{NH}_{2}$-LRQFFKKLPSPPFLPPTGADCR-COOH) were prepared on an Applied Biosystems 430A peptide synthesizer. Peptides were purified by high-performance liquid chromatography (HPLC), covalently coupled to keyhole limpet hemocyanin, and used to immunize rabbits as described previously (Landschulz et al. 1988a). Antiserum specific to a 14-amino-acid peptide of $\mathrm{C} / \mathrm{EBP} \alpha$ has been described previously (Landschulz et al. 1988a). The specificity of the antiserum preparations was tested with bacterially expressed polypeptides corresponding to the bZIP domains of each C/EBP isoform. No cross-reactivity was observed between the various antisera and polypeptides, consistent with the fact that the sequences of the synthetic antigens were unrelated.

\section{Western blot analysis}

HepG2 cells transfected with plasmids expressing different C/EBP isoforms were washed with phosphate-buffered saline (PBS) and scraped off of the tissue culture dish in $1 \mathrm{ml}$ of PBS. Cells were pelleted in a microcentrifuge tube, lysed by the addition of $100 \mu \mathrm{l}$ of SDS-gel sample buffer, and heated to $100^{\circ} \mathrm{C}$ for $5 \mathrm{~min}$. Twenty-five-microliter aliquots of each sample were electrophoresed through a $10 \%$ SDS-polyacrylamide gel (Laemmli 1970|. Electrophoresis proteins were then transferred to nitrocellulose filters and probed with appropriate antiserum preparations (Towbin et al. 1979). Immunoreactive polypeptides were visualized by the ECL detection system (Amersham), following procedures recommended by the supplier. To monitor the expression patterns of C/EBP isoforms as a function of 3T3L1 cell differentiation, protein extracts were prepared and used for Western blot analyses as described previously (Friedman et al. 1989|.

\section{Acknowledgments}

We thank Dr. Jon Shuman for providing purified polypeptides corresponding to $\mathrm{C} / \mathrm{EBP} \alpha$ and for his extensive help in preparing and purifying bacterially expressed polypeptides corresponding to C/EBP $\beta$ and C/EBP $\delta$. We acknowledge the extensive help of Brien Byers for the preparation and purification of synthetic peptides, Robert Kingsbury and Elizabeth Ryan for expert technical assistance, and Ed Birkenmeier for communicating unpublished observations regarding the genetic mapping and tissue distributions of expression of C/EBP $\beta$ and C/EBPS. Finally, we acknowledge contributions made by Peter Johnson, who first discovered that a radiolabeled DNA fragment corresponding to the DNA-binding domain of C/EBP was capable of hybridizing to multiple restriction fragments of mammalian DNA. During the course of these studies, Johnson isolated genomic copies of genes encoding three $\mathrm{C} / \mathrm{EBP} \alpha$-related proteins This work was supported by funds provided to S.L.M. by the Howard Hughes Medical Institute and the Carnegie Institution of Washington. R.M.U. was supported by a postdoctoral fellowship from the Leukemia Society of America, and Z.C. was supported by a 
postdoctoral fellowship from the Howard Hughes Medical Institute.

The publication costs of this article were defrayed in part by payment of page charges. This article must therefore be hereby marked "advertisement" in accordance with 18 USC section 1734 solely to indicate this fact.

\section{References}

Agre, P., P.F. Johnson, and S.L. McKnight. 1989. Cognate DNA binding specificity retained after leucine zipper exchange between GCN4 and C/EBP. Science 246: 922-926.

Akira, S., H. Isshiki, T. Sugita, O. Tanabe, S. Kinoshita, Y. Nishio, T. Nakajima, T. Hirano, and T. Kishimoto. 1990. A nuclear factor for Il-6 expression (NF-IL6) is a member of a C/EBP family. EMBO I. 9: 1897-1906.

Barinaga, M. 1991. Dimers direct development. Science 251: 1176-1177.

Bemlohr, D.A., C.W. Angus, M.D. Lane, M.A. Bolanowski, and T.J. Kelly. 1984. Expression of specific mRNA during adipose differentiation: Identification of an mRNA encoding a homologue of myelin P2 protein. Proc. Natl. Acad. Sci. 81: $5468-5472$.

Berkowitz, L.A. and M.Z. Gilman. 1990. Two distinct forms of active transcription factor CREB (cAMP response element binding protein). Proc. Natl. Acad. Sci. 87: 5258-5262.

Birkenmeier, E.H., B. Gwynn, S. Howard, J. Jerry, J.I. Gordon, W.H. Landschulz, and S.L. McKnight. 1989. Tissue-specific expression, developmental regulation, and genetic mapping of the gene encoding CCAAT/enhancer binding protein. Genes \& Dev. 3: 1146-1156.

Chang, C.-J., T.-T. Chen, H.-Y. Lei, D.-S. Chen, and S.-C. Lee. 1990. Molecular cloning of a transcription factor, AGP/EBP, that belongs to members of the C/EBP family. Mol. Cell. Biol. 10: 6642-6653.

Chomczynski, P. and N. Sacchi. 1987. Single-step method of RNA isolation by acid guanidinium thiocyanate-phenolchloroform extraction. Anal. Biochem. 162: 156-159.

Christy, R.J., V.W. Yang, J.M. Ntambi, D.E. Geiman, W.H. Landschulz, A.D. Friedman, Y. Nakabeppu, T.J. Kelly, and M.D. Lane. 1989. Differentiation-induced gene expression in 3T3-L1 preadipocytes: CCAAT/enhancer binding protein interacts with and activates the promoters of two adipocytespecific genes. Genes \& Dev. 3: 1323-1335.

Christy, R.J., K.H. Kaestner, D.E. Geiman, and M.D. Lane. 1991. CCAAT/enhancer binding protein gene promoter: Binding of nuclear factors during differentiation of 3T3-L1 preadipocytes. Proc. Natl. Acad. Sci. 88: 2593-2597.

Cohen, D.R. and T. Curran. 1988. fra-1: A serum inducible, cellular immediate-early gene that encodes a Fos-related antigen. Mol. Cell. Biol. 8: 2063-2069.

Corpet, F. 1988. Multiple sequence alignment with hierarchical clustering. Nucleic Acids Res. 16: 10881-10890.

Descombes, P., M. Choikier, S. Lichtsteiner, E. Falvey, and U. Schibler. 1990. LAP, a novel member of the C/EBP gene family, encodes a liver-enriched transcriptional activator protein. Genes \& Dev. 4: 1541-1551.

Dobson, D.E., D.L. Groves, and B.M. Spiegelman. 1987. Nucleotide sequence and hormonal regulation of mouse glycerophosphate dehydrogenase mRNA during adipocyte and muscle cell differentiation. J. Biol. Chem. 262: 1804-1809.

Fried, M. and D.M. Crothers. 1981. Equilibria and kinetics of lac repressor-operator interactions by polyacrylamide gel electrophoresis. Nucleic Acids Res. 9: 6505-6525.

Friedman, A.D. and S.L. McKnight. 1990. Identification of two polypeptide segments of CCAAT/enhancer-binding protein required for transcriptional activation of the serum albumin gene. Genes \& Dev. 4: 1416-1426.

Friedman, A.D., W.H. Landschulz, and S.L. McKnight. 1989. CCAAT/enhancer binding protein activates the promoter of the serum albumin gene in cultured hepatoma cells. Genes \& Dev. 3: 1314-1322.

Graham, F.L. and A.J. Van der Eb. 1973. A new technique for the assay of infectivity of human adenovirus 5 DNA. Virology 52: $456-457$

Graves, B.J., R.N. Eisenman, and S.L. McKnight. 1985. Delineation of transcriptional control signals within the Moloney murine sarcoma virus long terminal repeat. Mol. Cell. Biol. 5: 1948-1958.

Green, H. and O. Kehinde. 1974. Sublines of mouse 3T3 cells that accumulate lipid. Cell 1: 113-116.

- 1975. An established preadipose cell line and its differentiation in culture II. Factors affecting the adipose conversion. Cell 5: 19-27.

Hai, T., F. Liu, W.J. Coukos, and M.R. Green. 1989. Transcription factor ATF cDNA clones: An extensive family of leucine zipper proteins able to selectively form DNA-binding heterodimers. Genes \& Dev. 3: 2083-2090.

Halazonetis, T.D., K. Georgopoulos, M.E. Greenberg, and P. Leder. 1988. c-Jun dimerizes with itself and with c-Fos, forming complexes of different DNA binding affinities. Cell 55: $917-$ 924.

Hirai, S.-I., R.-P. Ryseck, F. Mechta, R. Bravo, and M. Yaniv. 1989. Characterization of junD: A new member of the jun proto-oncogene family. EMBO I. 8: 1433-1439.

Hoeffler, J.P., T.E. Meyer, Y. Yun, J.L. Jameson, and J.F. Habener. 1988. Cyclic-AMP-responsive DNA-binding protein: Structure based on a cloned placental cDNA. Science 242: $1430-1433$

Hope, I.A. and K. Struhl. 1987. GCN4, a eukaryotic transcriptional activator protein, binds as a dimer to target DNA. $E M B O$ I. 6: 2781-2784.

Ivashkiv, L.B., H.-C. Liou, C.J. Kara, W.W. Lamph, I.M. Verma, and L.H. Glimcher. 1990. mXBP/CRE-BP2 and c-Jun form a complex which binds to the cyclic AMP, but not to the 12O-tetradecanoylphorbol-13-acetate, response element. Mol. Cell. Biol. 10: 1609-1621.

Kaestner, K.H., R. J. Christy, and M. D. Lane. 1990. Mouse insulin-responsive glucose transporter gene: Characterization of the gene and trans-activation by the CCAAT/enhancer binding protein. Proc. Natl. Acad. Sci. 87: 251-255.

Kouzarides, T. and E. Ziff. 1988. The role of the leucine zipper in the fos-jun interaction. Nature 336: 646-651.

Laemmli, U.D. 1970. Cleavage of structural proteins during the assembly of the head of bacteriophage T4. Nature 227: 680685.

Landschulz, W.H., P.F. Johnson, E.Y. Adashi, B.J. Graves, and S.L. McKnight. 1988a. Isolation of a recombinant copy of the gene encoding C/EBP. Genes \& Dev. 2: 786-800.

Landschulz, H.W., P.F. Johnson, and S. L. McKnight. 1988b. The leucine zipper: A hypothetical structure common to a new class of DNA binding proteins. Science 240: 1759-1764.

- 1989. The DNA binding domain of the rat liver nuclear protein C/EBP is bipartite. Science 243: 1681-1688.

Lee, S.-J. 1990. Identification of a novel member (GDF-1) of the transforming growth factor- $\beta$ superfamily. Mol. Endocrinol. 4: $1034-1040$.

Lehrach, H., D. Diamond, J.M. Wozney, and H. Boedtker. 1977. RNA molecular weight determinations by gel electrophoresis under denaturing conditions, a critical reexamination. Biochemistry 16: 4743 . 
Lichtsteiner, S., J. Wuarin, and U. Schibler. 1987. The interplay of DNA-binding proteins on the promoter of the mouse albumin gene. Cell 51: 963-973.

Lin, Y.S. and M.R. Green. 1988. Interaction of a common cellular transcription factor, ATF, with regulatory elements in both Ela- and cyclic AMP-inducible promoters. Proc. Natl. Acad. Sci. 85: 3396-3400.

McKnight, S.L. 1980. The nucleotide sequence and transcript map of the herpes simplex virus thymidine kinase gene. Nucleic Acids Res. 8: 5949-5964.

McKnight, S.L., E.R. Gavis, and R. Kingsbury. 1981. Analysis of transcriptional signals of the HSV thymidine kinase gene: Identification of an upstream control region. Cell 25: 385398.

Maki, Y., T.J. Bos, C. Davis, M. Starbuck, and P.K. Vogt. 1987. Avian sarcoma virus 17 carries the jun oncogene. Proc. Natl. Acad. Sci. 84: 2848-2852.

Murre, C., P.S. McCaw, and D. Baltimore. 1989a. A new DNA binding and dimerization motif in immunoglobulin enhancer binding, daughterless, $\mathrm{MyoD}$, and myc proteins. Cell 56: 777-783.

Murre, C., P.S. McCaw, H. Vaessin, M. Caudy, L.Y. Jan, Y.N. Jan, C.V. Cabrera, J.N. Buskin, S.D. Hauschka, A.B. Lassar, H. Weintraub, and D. Baltimore. 1989b. Interactions between heterologous helix-loop-helix proteins generate complexes that bind specifically to a common DNA sequence. Cell 58: $537-544$.

Nishina, H., H. Sato, T. Suzuki, M. Sato, and H. Iba. 1990. Isolation and characterization of fra-2, an additional member of the fos gene family. Proc Natl. Acad. Sci. 87: 3619-3623.

Olson, E.R. 1990. MyoD family: A paradigm for development? Genes \& Dev. 4: 1454-1461.

O'Shea, E.K., R. Rutkowski, and P.S. Kim. 1989. Evidence that the leucine zipper is a coiled coil. Science 243: 538-542.

Park E.A., W.J. Roesler, J. Liu, D.J. Klemm, A.L. Gurney, J.D. Thatcher, J.D. Shuman, A. Friedman, and RW. Hanson. 1990. The role of the CCAAT /enhancer-binding protein in the transcriptional regulation of the gene for phosphoenolpyruvate carboxykinase (GTP). Mol. Cell. Biol. 10: 6264 6272.

Pei, D. and C. Shih. 1991. An "attenuator domain" is sandwiched by two distinct transactivation domains in the transcription factor C/EBP. Mol. Cell. Biol. 11: 1480-1487.

Poli, V., F.P. Mancini, and R. Cortese. 1990. IL-6DBP, a nuclear protein involved in interleukin-6 signal transduction, defines a new family of leucine zipper proteins related to C/EBP. Cell 63: 643-653.

Rauscher, F.J., III, P.J. Voulalas, B.R. Franza, Jr., and T. Curran. 1988. Fos and Jun bind cooperatively to the Ap-l site: Reconstitution in vitro. Genes \& Dev. 2: 1687-1699.

Roman, C., J.S. Platero, J.D. Shuman, and K. Calame. 1990. Ig/EBP-1: A ubiquitously expressed immunoglobulin enhancer binding protein that is similar to C/EBP and heterodimerizes with C/EBP. Genes \& Dev. 4: 1404-1415.

Rosenberg, A.H., B.N. Lade, D.-S. Chui, S.-W. Lin, J.J. Dunn, and F.W. Studier. 1987. Vector for selective expression of cloned DNAs by T7 RNA polymerase. Gene 56: 125-135.

Rubin, C.S., E. Lai, and O.M. Rosen. 1977. Acquisition of increased hormone sensitivity during in vitro adipocyte development. I. Biol. Chem. 252: 3554-3557.

Russell, T.R. and R.-J. Ho. 1976. Conversion of 3 T3 fibroblasts into adipose cells: Triggering of differentiation by prostaglandin $\mathrm{F}_{2 \alpha}$ and 1-methyl-3-isobutylxanthine. Proc. Natl. Acad. Sci. 73: 4516-4520.

Ryder, K. and D. Nathans. 1988. Induction of protooncogene c-jun by serum growth factors. Proc. Natl. Acad. Sci.
85: 8464-8467.

Ryder, K., A. Lanahan, E. Perez-Albuerne, and D. Nathans. 1989. Jun-D: A third member of the Jun gene family. Proc. Natl. Acad. Sci. 86: 1500-1503.

Sassone-Corsi, P., W.W. Lamph, M. Kamps, and I.M. Verma. 1988. Fos- associated cellular p32 is related to nuclear transcription factor AP-1. Cell 54: 553-560.

Scatchard, G. 1949. The attractions of proteins for small molecules and ions. Ann. N.Y. Acad. Sci. 51: 660-672.

Shuman, J.D., C.R. Vinson, and S.L. McKnight. 1990. Evidence of changes in protease sensitivity and subunit exchange rate on DNA binding by C/EBP. Science 249: 771-774.

Smeal, T., P. Angel, J. Meek, and M. Karin. 1989. Different requirements for formation of Jun : Jun and Jun : Fos complexes. Genes \& Dev. 3: 2091-2100.

Struhl, K. 1989. Molecular mechanisms of transcriptional regulation in yeast. Annu. Rev. Biochem. 58: 1051-1077.

Student, A.K., R.Y. Hsu, and M.D. Lane. 1980. Induction of fatty acid synthetase synthesis in differentiating 3T3-Ll preadipocytes. J. Biol. Chem. 255: 4745-4750.

Studier, F.W. and B.A. Moffatt. 1986. Use of bacteriophage T7 RNA polymerase to direct selective high-level expression of cloned genes. J. Mol. Biol. 189: 113-130.

Towbin, H., T. Staehelin, and J. Gerdon. 1979. Electrophoretic transfer of proteins from polyacrylamide gels to nitrocellulose sheets: Procedure and some applications. Proc. Natl. Acad. Sci. 76: 4350-4354.

Umek, R.M., A.D. Friedman, and S.L. McKnight. 1991. CCAAT/enhancer binding protein: A component of a differentiation switch. Science 251: 288-292.

Van Beveren, C., F. Van Straaten, T. Curran, R. Muller, and I.M. Verma. 1983. Analysis of FBJ-MuSV provirus and c-fos (mouse) gene reveals that viral and cellular fos gene products have different carboxy termini. Cell 32: 1241-1255.

Vinson, C.R., P.B. Sigler, and S.L. McKnight. 1989. Scissors-grip model for DNA recognition by a family of leucine zipper proteins. Science 246: 911-916.

Zaret, K.S., C.M. DiPersio, D.A. Jackson, W.J. Montigny, and D.L. Weinstat. 1988. Conditional enhancement of liver-specific gene transcription. Proc. Natl. Acad. Sci. 85:90769080.

Zerial, M., L. Toschi, R.-P. Ryseck, M. Schuermann, R. Miller, and $\mathrm{R}$ Bravo. 1989. The product of a novel growth factor activated gene, fosB, interacts with JUN proteins enhancing their DNA binding activity. $E M B O$ I. 8: 805-813. 


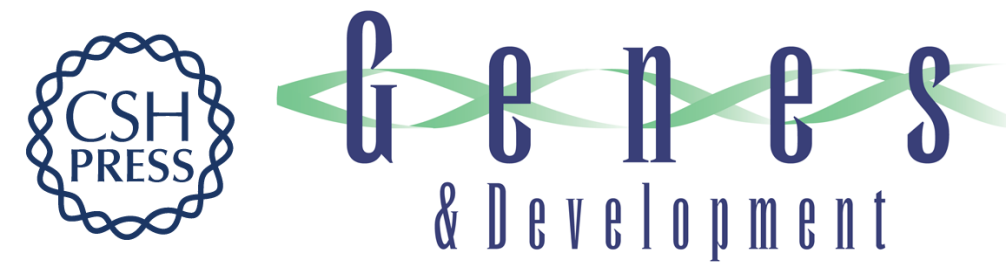

\section{Regulated expression of three C/EBP isoforms during adipose conversion of 3T3-L1 cells.}

Z Cao, R M Umek and S L McKnight

Genes Dev. 1991, 5:

Access the most recent version at doi:10.1101/gad.5.9.1538

References This article cites 68 articles, 41 of which can be accessed free at: http://genesdev.cshlp.org/content/5/9/1538.full.htmI\#ref-list-1

\section{License}

Email Alerting

Receive free email alerts when new articles cite this article - sign up in the box at the top Service right corner of the article or click here.

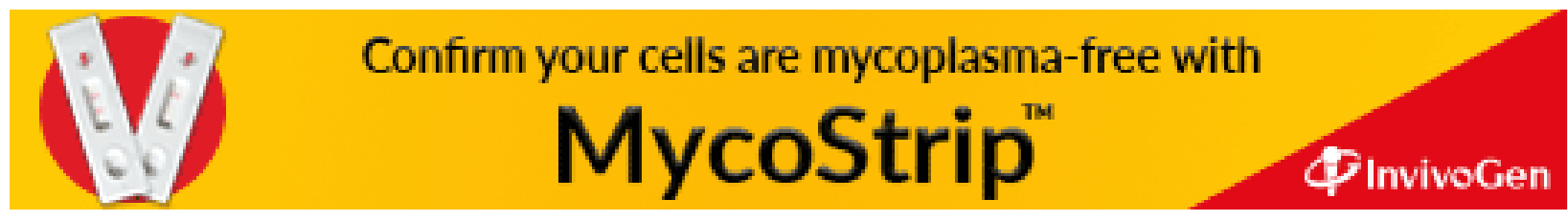

